\title{
Plastics in Heritage Collections: Poly(vinyl chloride) Degradation and Characterization
}

\section{Tjaša Rijavec ${ }^{1}$, Matija Strlic $\check{c}^{1,2,3}$ and Irena Kralj Cigić ${ }^{1,4, *}$}

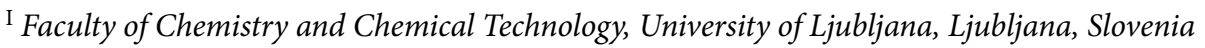

${ }^{2}$ Institute for Sustainable Heritage, University College London, London, UK

${ }^{3}$ Museum Conservation Institute, Smithsonian Institution, Suitland MD, USA

${ }^{4}$ Department of Chemical and Pharmaceutical Sciences, University of Trieste, Trieste, Italy

*Corresponding author: E-mail: irena.kralj-cigic@fkkt.uni-lj.si

Received: 11-01-2020

\begin{abstract}
Museums and galleries house increasingly large collections of objects and contemporary art made of plastic materials, many of which undergo rapid material change. The main degradation processes of poly(vinyl chloride) (PVC) are elimination of $\mathrm{HCl}$ and plasticizer migration or leaching. This results in visible discolouration, stickiness and cracking. Degradation is known to be a multi-stage process that includes $\mathrm{HCl}$ elimination, formation of conjugated polyenes and cross-linking. Elimination of $\mathrm{HCl}$ begins due to structural irregularities (allylic and tertiary chlorides) and results in the formation of polyenes. When at least 7 conjugated double bonds are present, discolouration of PVC becomes visible.

Non-invasive techniques, such as IR and Raman spectroscopy are used for polymer identification and plasticizer quantification. Plasticizer degradation and particularly the late stages of PVC degradation can be investigated using SEC, GC-MS, TGA and DSC. Studies in heritage collections have revealed that, apart from $\mathrm{HCl}$, PVC objects emit 2-ethylhexanol and other volatile degradation products, however, there is currently no indication that $\mathrm{HCl}$ is emitted at usual indoor conditions. There seems to be a general lack of systematic research into PVC degradation at the conditions of storage and display, which could result in the development of dose-response functions and in the development of preventive conservation guidelines for the management of PVC collections.
\end{abstract}

Keywords: poly(vinyl chloride); plastics; non-destructive characterization; heritage collections; accelerated degradation

\section{Introduction}

In the $20^{\text {th }}$ century, poly(vinyl chloride) (PVC) and other plastics have achieved widespread use in daily life ${ }^{1}$, with more than $5 \mathrm{M}$ tonnes of PVC produced in Europe in 2018 alone, representing $10 \%$ of all plastic. $^{2}$ The evolution of artform has gone hand in hand with the discovery and invention of new materials, and plastics were no exception. ${ }^{3,4}$ Many museums have significant collections of plastic objects from the late $19^{\text {th }}$ and $20^{\text {th }}$ century, as well as art made from plastic materials (Figure 1)..$^{5-7}$
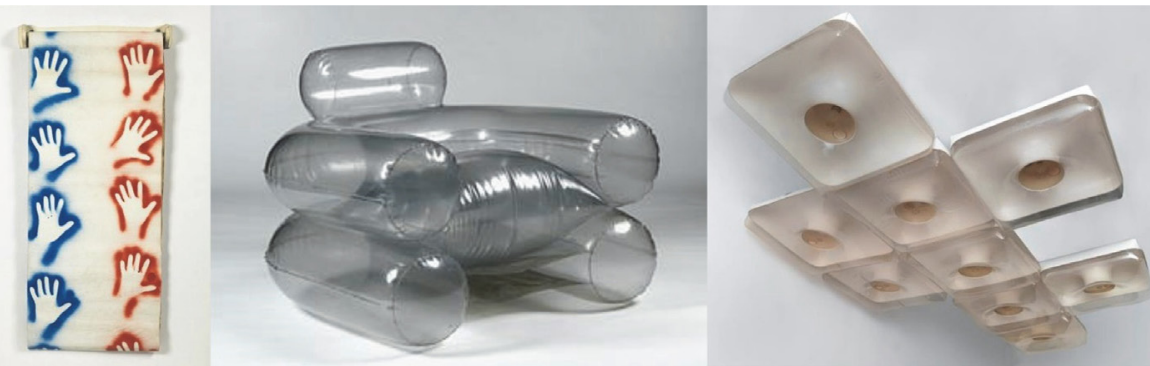

Figure 1: Examples of PVC art and design objects. Left: Essuie-mains / Hygiène de l'art, 1971 (inv. no. AM 2006-114) by Hervé Fischer, middle: Fauteuil Blow, 1967 (inv. no. AM 2007-1-38), by de Pas, D’Urbino, Lomazzi, right: Plafonnier, 1968 (inv. no. AM 2007-1-5) by Quasar (Nguyen Manh Khan'h). Reproduced with permission of MNAM, Centre Pompidou, Paris, France. 
A survey of museum collections in France, Netherlands and the United Kingdom was carried out in the scope of the project POPART during 2008-2012. ${ }^{5}$ The results showed that PVC was present in all collections and represented $13 \%$ of all plastic objects. The degradation state was also assessed and $68 \%$ of objects in the collection were in a good or fair state, $25 \%$ were in a state of significant decay and $7 \%$ were severely damaged. Cellulose acetate $(\mathrm{CA})$, cellulose nitrate $(\mathrm{CN})$ and $\mathrm{PVC}$ represented $40 \%$ of all objects in poor state. ${ }^{5}$ Plasticized PVC was a major commodity plastic found in the collection of the Museé d'art moderne et d'art contemporain (MAMAC) in Nice, France, and in the Musée d'art moderne de SaintEtienne Métropole (MAM). The surveys had also exposed the problem of museums having a lack of reliable information regarding the identity of the polymers before the FTIR and Py-GC-MS analysis was carried out . ${ }^{8}$

Pure PVC is a solid brittle material, which makes it difficult to process and mould. It has poor thermal properties, as is prone to distorting when exposed to temperatures above $60^{\circ} \mathrm{C}$. Its discovery in 1872 by Eugen Baumann was not immediately followed by commercialization due to the difficulties with processing of this rigid and brittle pure polymer. ${ }^{9}$ However, PVC's mechanical and thermal properties, such as density, tensile strength, electrical resistance and elastic properties can be modified with additives. In 1926, Waldo Semon and the B.F. Goodrich Company introduced additives to soften the PVC, making it easier to process, which led to worldwide commercial usage. Heat stabilizers, UV stabilizers, plasticizers, fillers, pigments, thermal modifiers, flame retardants, biocides and other modifiers are used to produce items for specific purposes. Additives are used to improve technological processing, the plastic's final characteristics and performance. Fillers, such as carbonates and silicates, are used to reduce the production costs and increase impact resistance. ${ }^{10}$ Plasticizers act as softeners and reduce the viscosity of the polymer. They can make up to $50 \%$ of the final formulation in flexible PVC. $3,11,12$ Heat stabilizers are included in most commercial PVC formulations to prevent thermal degradation, neutralize the emitted $\mathrm{HCl}$, replace labile chlorine in PVC and prevent oxidation. Light stabilizers protect the material from thermal and UV degradation, while antioxidants prevent oxidation. Pigments are added to change the colour of the plastic. Unplasticized PVC is the material of choice for making electrical insulation boxes, pipes and electric cables, windows and flooring. Plasticized PVC is used to form clothing, tubes in healthcare, toys, vinyl records, food packaging, greenhouse windows and shower curtains. ${ }^{1,12,13}$

The aim of this review is to address what appears to be a significant lack of attention to PVC as a collection material. We will briefly discuss the mechanisms of thermal degradation of PVC, describe the determination of the material state of PVC with a particular focus on analytical techniques that provide useful information to make informed conservation decisions, and review the research on
PVC degradation in heritage and museum collections. Many researchers studying commodity plastics focus on early-stage degradation and not on the advanced degradation relevant to museum objects. Early-stage degradation of commodity plastics in the first few years since production is important in the plastic industry to provide the guaranteed lifetime of the object. However, objects can become part of museum collections and retain their value as cultural heritage long after their useful lifetime as consumer products, defined by industrial standards, has ended. ${ }^{3}$ Tackling advanced stages of degradation is thus important for preserving such objects.

We focus specifically on research into PVC and its degradation at moderate temperatures, as this could form the basis for modelling of degradation at environmental conditions of storage and display. There are numerous monographs and reviews approaching the problem from different angles of interest. Shashoua's seminal volume on the conservation of plastics in museum collections discusses the history of technology development, properties of plastics and their degradation. ${ }^{3}$ The production and application of PVC are addressed in a volume by Patrick. ${ }^{1}$ Wypych's book thoroughly addresses degradation and stabilization of PVC with a focus on industrial stabilizers, ${ }^{12}$ while the mechanistical aspects of degradation are covered by Starnes in detail. ${ }^{14-16} \mathrm{~A}$ review on volatile organic compounds (VOCs) emitted from plastics and rubbers in conservation, heritage science, construction and polymer science demonstrates examples of degradation markers for certain polymers. ${ }^{17}$ Current trends and challenges in investigating the plasticizer loss mechanism and rates in heritage collections have been reviewed by King. ${ }^{18}$ It is also well known how recycling affects the thermal degradation of PVC. ${ }^{19}$ The decomposition of PVC by microorganisms appears to be an emerging area of interest. ${ }^{20}$

Classical art collections contain traditional materials such as ceramics, stone, metals, paper and textiles, and conservation issues related to such objects have been studied for long, they are therefore relatively well understood, and guidelines are available to extend their lifetimes. ${ }^{21-26}$ For many plastic objects, especially those made of cellulose nitrate, cellulose acetate, poly(vinyl chloride) or polyurethane, which are frequent in collections and prone to deterioration, the lifetime can be orders of magnitude shorter than for traditional organic materials such as paper, oil paint or parchment. ${ }^{3,24,25,27,28}$ In addition, the degradation of plastics in museums does not result only in the loss of integrity and value of the objects themselves but can lead to the deterioration of objects in their vicinity due to the formation of harmful substances e.g. acidic gasses. ${ }^{29}$

\section{Plasticization of Poly(vinyl Chloride)}

Most PVC objects in heritage collections are made of plasticized PVC. The physical and chemical degradation of 
the plasticizer itself also directly dictates the current state and the degradation of PVC objects. Migration of plasticizers makes the surface sticky and hydrolysis of certain plasticizers may lead to the formation of white crystals on the surface, which changes the object's appearance. It also leads to warping and cracking, all of which negatively impacts the state of the object.

Commodity plastics, such as PVC, are plasticized externally, where the plasticizer is not chemically bonded and acts as a solvent for the polymer. Internal plasticizers are chemically bonded to the polymer by modification of the polymer backbone or by bonding to the backbone. Such engineering plastics are rare and formed during manufacture. Primary external plasticizers are highly compatible with the polymer and can be added in large quantities, while secondary plasticizers have high volatility or only limited compatibility with the polymer and are used in combination with primary plasticizers. ${ }^{11,30}$ Plasticizers must solvate the polymer and cannot be prone to self-association, which makes esters appropriate compounds. Ideally, plasticizers should be stable, non-toxic, non-volatile, odourless, colourless liquids.

\section{1. Types of Plasticizers}

More than $90 \%$ of all plasticizers are used in the PVC industry. ${ }^{31} \mathrm{PVC}$ is the only commercial polymer that can retain large concentrations of plasticizers. A major group of traditional and current plasticizers are ortho-phthalate esters. Low molecular weight ortho-phthalates $\left(\mathrm{C}_{4}-\mathrm{C}_{7}\right.$ alcohols) were historically used in many PVC formulations. They have been classified as substances of very high concern in Europe and United States of America ${ }^{32}$ and are being replaced with high molecular weight ortho-phthalates, terephthalates and benzoate plasticizers.

Primary common PVC plasticizers are long-chain esters of phthalic acid, of which $75 \%$ represent di(2-ethylhexyl) phthalate (DEHP or DOP), diisononyl phthalate (DINP) and diisodecyl phthalate (DIDP) (Figure 2). ${ }^{11,33}$ DEHP had been accepted as the standard all-purpose plasticizer until it was labelled as a reproductive toxicant in Europe. ${ }^{34}$ It was replaced with DINP, DIDP, dipropylheptyl phthalate (DPHP) and its terephthalate analogue di(2-ethylhexyl) terephthalate (DEHT or DOTP) ${ }^{31}$ In the
USA, manufacturers of children's toys are prohibited from using 8 ortho-phthalates. ${ }^{35}$ Diesters of terephthalic acid have replaced DEHP in many applications, including sensitive products such as toys, medical and food products. ${ }^{30}$ Hydrogenation of ortho-phthalates produces 1,2-cyclohexane dicarboxylates which are also used as plasticizers. Mono- and di-benzoates of branched $\mathrm{C}_{8}-\mathrm{C}_{10}$ alcohols are often used as secondary plasticizers due to their high compatibility and high solvating power. Dibenzoate plasticizers have high viscosity so they are used in combination with primary plasticizers DINP, DIDP, DPHP and DEHT. Alkyl adipate esters have low intrinsic viscosity and good flexibility properties. Di(2-ethylhexyl) adipate (DEHA) is widely used in PVC clingfilm for food storage. Trimellitate esters have very low volatility and are resistant to extraction. ${ }^{36}$ Tris(2-ethylhexyl) trimellitate (TOTM or TEHTM) is the most common, as it is approved for use in medical devices. Other commonly used plasticizers are citrates, such as acetyl tributyl citrate (ATBC), adipates (e.g. diisononyl adipade DINA), and sebacates (e.g. dibutyl sebacate DBS).

The most common secondary plasticizers are chlorinated hydrocarbons, isobutyrate esters and epoxidized oils. TXIB (2,2,4-trimethyl-1,3-pentandiol diisobutyrate) is a secondary plasticizer used in many PVC formulations to lower the cost of production and decrease the viscosity of plastisols. It is more volatile than long-chain phthalate esters, so the emissions of VOCs are increased.

Research and development of new plasticizers has recently focused on biobased plasticizers. A possible alternative is epoxidized soybean oil (ESBO), which is an efficient plasticizer and heat stabilizer for PVC. ${ }^{13}$ It is used as a plasticizer in modern toys, as replacement for DEHP. Its cost is comparable to the traditional DEHP, but ESBO is also prone to migration. Acetylated and epoxidized cardanol was used to form plasticized PVC and investigate its tensile properties, UV and thermal degradation. ${ }^{37}$ It had good mechanical properties and acted as a UV and heat stabilizer. The drawback is that it produced PVC darker in colour than traditional plasticizers. Epoxide groups in the structure of epoxidized plasticizers scavenge hydrochloric acid to form chlorohydrins and improve their thermal stability by reducing the rate of degradation. This inhibits thermal degradation by affecting the first

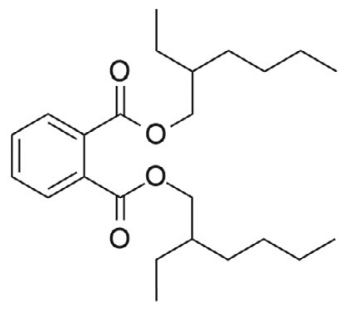

DEHP

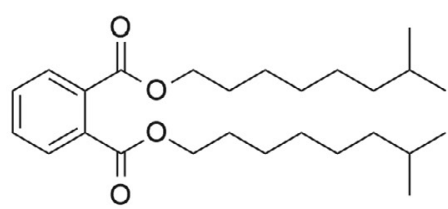

DINP

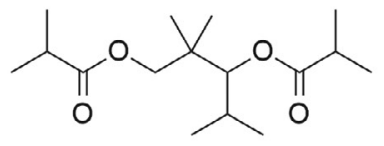

TXIB

Figure 2: Common PVC plasticizers: di(2-ethylhexyl) phthalate (DEHP), diisononyl phthalate (DINP) and 2,2,4-trimethyl-1,3-pentandiol diisobutyrate (TXIB). 
stage of degradation described in Section 2.3. A castor oilbased plasticizer has improved elongation and tensile properties of PVC. ${ }^{38}$ A plasticizer based on epoxidized cottonseed oil (ECSO) has been shown to have comparable tensile and elongation properties to the traditional plasticizer DEHP. ${ }^{39}$ The usual curing temperature of plastisols with phthalate esters is $160{ }^{\circ} \mathrm{C}$, but ECSO requires higher temperatures up to $220^{\circ} \mathrm{C}$, where thermal degradation for PVC is significant. Cardanol is the main component of cashew nut oil, used to make epoxidized cardanol glycidyl ether. ${ }^{40}$ It was tested as a plasticizer in making PVC films and demonstrated to have better thermal stability than films made with DEHP. Other plasticizers derived from raw materials, especially citrates, succinates, triglycerides, sugar derivatives and fatty acid esters have been synthesized and used as alternative plasticizers. ${ }^{30,41}$

New biobased plasticizers were tested in finished PVC formulation. Despite the accelerated degradation tests of emerging plasticizers, there are still uncertainties about the natural lifelong stability and performance of PVC products created with emerging plasticizers. As an example, a study of PVC plasticized with ESBO demonstrated that the presence of traditional stabilizers, such as calcium and zinc stearates, decreased the stability of PVC-ESBO system. ${ }^{42}$

To summarize, long-chain phthalates, terephthalates, trimellitates, adipates, sebacates and citrates are the most commonly used plasticizers in soft PVC. Sometimes secondary plasticizers, such as TXIB, are used to decrease the viscosity of plastisols and lower the production costs. DEHP was traditionally the most commonly used plasticizer and is likely currently the most prevalent in collections. However, it was prohibited for use in childcare articles and items in prolonged contact with skin. Recently, biobased plasticizers, such as ESBO, have been proposed as good alternatives.

\section{2. Mechanisms of Plasticization}

Four different theories explaining the mechanism of plasticization have been developed. ${ }^{11,43}$ The lubricity theory, developed by Kilpatrick, Clark and Houwink, explains that in the presence of plasticizers, the polymer chains can easily move over each other due to uneven attraction to different segments of the plasticizer molecules. ${ }^{43}$ The polar segment of a plasticizer acts as a solvent for the polymer while the non-polar segment acts as a lubricant, allowing the polymer chains to move freely. The gel theory, developed by Aiken, proposes the formation of a gel structure by permanent intermolecular bonds or by the dynamic formation and breakage of bonds between the polymer chain and the plasticizer. ${ }^{44}$ External plasticizers have more freedom to solvate and desolvate different polymer sites while internal plasticizers lack this option and soften less with increasing temperature. This theory also explains that secondary plasticizers can soften PVC by increasing the space between polymer chains and reducing the association of polymer chains. The free volume theory is used to explain the decrease in glass transition temperature with the addition of plasticizer. ${ }^{11}$ Unplasticized PVC is hard and rigid because the motion of polymer chains is limited. The low free volume originates from limited motion of polymer end groups, motion of polymer side groups and internal polymer motions. Addition of plasticizers enables the motion of the plasticizer itself and increases the motion in polymer chains. Below the glass transition temperature such motions are limited, while above Tg the motions increase, which creates free volume. Kinetic and mechanistic theories view the associations between polymer and different plasticizers as transient. ${ }^{45}$ The dominating associations depend on the polymer to plasticizer ratio.

Plasticization of PVC with phthalates is possible due to the polar bond between carbon and chlorine which interacts with phthalic ester polar groups and the polar aromatic ring, forming dipole-dipole interactions. Such polymer-plasticizer interactions need to be of comparable strength to plasticizer-plasticizer interactions, otherwise mixing would be unfavourable and lead to migration and leaching of plasticizer.

A decrease of glass-transition temperature from 80 ${ }^{\circ} \mathrm{C}$ to below room temperature can be achieved with the addition of plasticizers. ${ }^{11}$ In general, the glass-transition temperature decreases with increasing weight fraction of the plasticizer (Table 1). The relationship is non-linear, but several simplistic functions have been used to predict the glass-transition temperature from known mass fractions and glass-transition temperatures of the starting polymer and plasticizer. ${ }^{11}$ Better agreement was achieved by using two different equations, separated by critical plasticizer content. More advanced mathematical models predicting the glass-transition temperature of plasticized PVC have also been developed. ${ }^{46}$ The critical plasticizer content is observed as a cusp in Tg vs. weight fraction of the plasticizer and indicates the most homogenous structure of plasticized PVC. ${ }^{47}$ Polymer-plasticizer interactions dominate below the critical plasticizer content and plasticizer-plasticizer interactions predominate at higher plasticizer concentrations, which adds to the heterogeneity of the

Table 1: Glass-transition temperatures for PVC with different mass fraction of DEHP. Approximate values summarized from the literature. ${ }^{11,47}$

\begin{tabular}{lrrrrrrrrrr}
\hline $\mathbf{w}(\mathbf{D E P H})[\%]$ & 100 & 60 & 50 & 40 & 35 & 30 & 25 & 20 & 10 & 0 \\
$\mathbf{T g}\left[{ }^{\circ} \mathrm{C}\right]$ & -80 & -60 & -50 & -20 & -10 & 5 & 10 & 25 & 55 & 80 \\
\hline
\end{tabular}


blend. In the case of PVC plasticized with DEHP, the critical plasticizer content is $\sim 30$ wt. $\%$ of DEHP.

Interestingly, an anti-plasticization effect can be observed with PVC mixtures containing less than 15 wt. \% DEHP in PVC. ${ }^{31,48}$ The small amount of plasticizer rearranges the PVC polymer chains and increases the crystallinity of PVC, which makes it more brittle than pure PVC. The plasticization effect becomes apparent with plasticizer content $>15 \mathrm{wt}$. \%. Plasticized PVC is in a rubbery state at room temperature, making it more flexible and ductile. Plasticization also decreases the tensile strength and the density of the plastic. ${ }^{49}$

Since most plasticizers are not chemically bonded to the polymer chain but only mixed with the polymer, the problem emerges due to their migration to the surface and leaching to materials in contact. ${ }^{50,51}$ Such migration leads to a loss of flexibility, increased brittleness and eventual cracking. ${ }^{52}$

Migration of plasticizer can lead to physical distortion (shrinking and warping) or increased brittleness of the material. ${ }^{49}$ The shrinkage of new PVC sheets decreases with increasing content of dioctyl phthalate plasticizer, because the plasticizer reduces polymer chain entanglements. ${ }^{53} \mathrm{PVC}$ membranes that experienced plasticizer loss had shrunk. ${ }^{54}$ Warping is a result of ductile failure, while crazing and cracking result from brittle failure and are more common at advanced stages of degradation, when more rigid polyene segments are formed. ${ }^{49}$

The fact that the glass transition temperature of PVC decreases with increasing plasticizer content has bearing on the relevance of accelerated degradation experiments conducted at elevated temperatures. Since phase transitions significantly affect reaction kinetics, experiments need to be conducted in temperature intervals in which the examined PVC material is in the same phase as at the conditions of storage and display. This would require either sufficiently low temperatures during accelerated degradation experiments (e.g. $<55{ }^{\circ} \mathrm{C}$ for PVC with $10 \%$ DEHP) or high enough concentrations of plasticizer. There is currently not enough information on how loss or migration of plasticizer affects the $\mathrm{Tg}$, and whether this changes significantly during degradation of the PVC polymer itself.

\section{3. Degradation Processes Involving Plasticizers}

Phthalate plasticizers are categorized as semi-volatile organic compounds and their loss depends on the diffusion from the bulk to the surface and evaporation. The rate-limiting process of plasticizer migration at room temperatures and in low air-flow conditions is evaporation from the surface while diffusion from the bulk becomes the rate-limiting step at higher temperatures, in high air flow environments or in vacuum. For PVC-DEHP systems this occurs at $110-120^{\circ} \mathrm{C} .{ }^{55}$ The rate of evaporation for a given substance depends on the temperature of the sub- stance, its concentration in the air (controlled by its volatility and air velocity) and the surface area.

In a study of PVC tubes exposed to a flow of nitrogen in an oven heated to $100{ }^{\circ} \mathrm{C}$, mass loss became constant and diffusion controlled at flow rates higher than $75 \mathrm{~mL} / \mathrm{min} .^{51}$ At room temperatures and in low air velocity, the loss of plasticizer is controlled by evaporation, so a thin film of plasticizer is present on the object surface. . $^{51,56,57}$ The layer is saturated with the plasticizer, which slows down the diffusion process from the bulk that is driven by a concentration gradient as described by Fick's law. The loss of plasticizers in such conditions is thought to be independent of plasticizer content and determined mostly by temperature, plasticizer polarity and volatility, flow-rate above the surface and volume of surrounding air. ${ }^{58}$ In closed environments with stagnant air, the plasticizer vapour pressure builds up and the evaporation is slowed down.

In a study of accelerated degradation at $80{ }^{\circ} \mathrm{C}$, this resulted in a 5\% mass loss after 20 weeks in a closed environment and a $25 \%$ mass loss in an open environment. ${ }^{59}$ This is in agreement with a study showing that the plasticizer loss rate is three-times higher in ventilated degradation conditions than in closed environments with stagnant air. ${ }^{60}$ Accelerated degradation of model PVC sheets by Shashoua also confirmed these observations. The evaporation rate of DEHP was not affected by humidity in studies by Ekelund ${ }^{51}$ and by Clausen ${ }^{61}$. Shashoua reported the mass loss was decreased in high-humidity environments, although this could result from water absorption. ${ }^{57}$

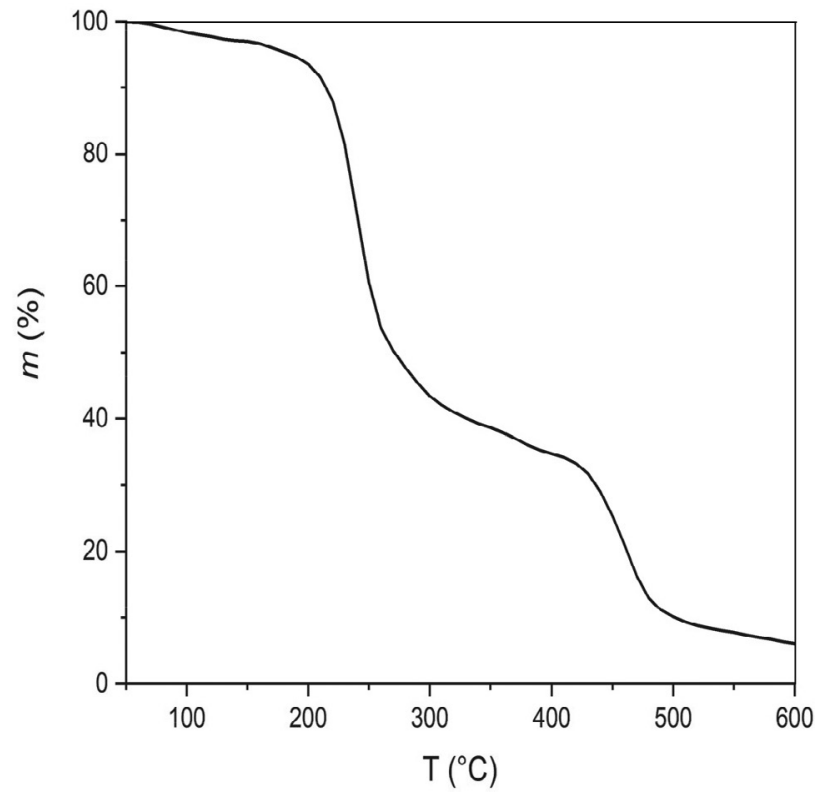

Figure 3: TGA thermogram of PVC. Degradation proceeds in two stages. From 190 to $350^{\circ} \mathrm{C}$ elimination of $\mathrm{HCl}$ takes place and chlorine is completely removed from the polymer. In the second stage $\left(350-550^{\circ} \mathrm{C}\right)$ conjugated polyenes form benzene, alkylated benzene and crosslink and thermal cracking of PVC's backbone also takes place and a variety of hydrocarbon products are released. Adapted from literature ${ }^{63,64}$. 
The processes of plasticizer evaporation and elimination of $\mathrm{HCl}$ from $\mathrm{PVC}$ are difficult to investigate since they occur simultaneously and both result in a mass loss. Evaporation of pure phthalate plasticizer has been studied by thermogravimetric analysis, but it seemed to occur at lower temperatures then in plastisol mixtures with the polymer, due to a lack of plasticizer-polymer interactions and no diffusion present. ${ }^{62}$ Many thermogravimetric studies of plasticized PVC are conducted at high temperatures (up to $250{ }^{\circ} \mathrm{C}$ ), where the mechanisms may not be representative and characteristic for the degradation at room temperatures (Figure 3).

The role of plasticizers and their concentration on the stability of a PVC formulation cannot be overgeneralized. Dioctyl azelate, dioctyl adipate and DEHP were found to linearly increase the stability of PVC plastisols with increasing concentration, while benzyl butyl phthalate, dibutyl phthalate and diphenyl octyl phosphate linearly decreased the stability with increasing concentration. ${ }^{11}$ Increasing the plasticizer content causes an increase of the dielectric constant of the material, which correlated to a loss of thermostability. The increased polarity of the medium could increase the elimination of hydrogen chloride. Contrary, plasticizers are believed to decrease the rate of dehydrochlorination due to dilution of the polymer and decreasing the probability of dehydrochlorination. ${ }^{11}$ It should be noted that these studies were conducted on PVC plastisols. The effect of different plasticizers and plasticizer concentrations on the stability of PVC objects is unclear. This may be due to the high variety of heat stabilizers and other additives that influence the stability of the final product, which makes the comparison difficult.

Plasticizers are also prone to degradation, which can occur as hydrolysis or oxidation. Phthalate esters are prone to hydrolysis to phthalic acid and emission of alkyl alcohols, which are volatile organic compounds. The hydrolysis is catalysed by acidic conditions, such as the emission of $\mathrm{HCl}$ from the degradation of PVC. DEHP can hydrolyse to phthalic acid at acidic or alkaline conditions, which can be visible as white crystals on the surface. ${ }^{3}$ In turn, phthalic acid also negatively affects the stability of PVC. ${ }^{11}$

An isothermal approach was taken to determine the loss of DEHP plasticizer from PVC and found it to be a first order kinetic process. ${ }^{62}$ The rate constants of volatilization were determined for four different concentrations of plasticizer at different temperatures ranging from 120 $150{ }^{\circ} \mathrm{C}$. The rate of evaporation was largely dependent on the temperature. The activation energy and preexponential factor of the volatilization of DEHP were determined with the Arrhenius equation and were found to increase with increasing DEHP concentration in the polymer. Exposure to outdoor conditions can cause the top layer to be exposed to an increased rate of plasticizer evaporation at higher temperatures and photo-degradation, which causes the surface to have different elastic behaviour than the bulk and may cause surface cracking. The concentration dependency of evaporation of plasticizer led to some con- troversy, where Braun and et al. have shown the relationship not to be linear and having a minimal value based on the chosen plasticizer and possible interactions. ${ }^{65,66}$ The highest compatibility of a plasticizer with polymer is designated as the critical concentration, but no studies were found to connect it with the lowest evaporation rate.

To briefly summarize, plasticizers are volatile and semi-volatile organic compounds that can migrate from the bulk and evaporate from the surface of plasticized PVC objects. Temperature, plasticizer volatility, air-low rate and the geometry of the object determine if the loss is controlled by evaporation or diffusion. Plasticizers are also prone to degradation. Phthalates degrade to phthalic acid and alkyl alcohols. The effect of plasticizers on the stability of PVC objects is unclear, as studies of thermal stability are rarely comparable due to vastly different PVC formulations, unknown identities and quantities of other additives, such as heat stabilizers. More studies are needed of the degradation products of stabilizers themselves in order to ensure that these do not represent a conservation risk.

\section{4. Evaluation of Migration of Phthalates}

Determination of the total phthalate content in PVC is possible using extraction with hexane, methanol or diisopropyl ether, but migrated phthalates can also be removed from the surface with water solutions of surfactants. ${ }^{3,11}$ Surface removal of phthalates can also take place in contact with adsorbent materials, such as polyester/polyamide cloths or low-density polyethylene (LDPE). ${ }^{57}$

FTIR analysis was used to quantify PVC and DEHP on the surface. ${ }^{67}$ In the study, model PVC sheets were made from plastisol containing two types of phthalate plasticizers, DEHP and 2,2,4-trimethyl-1,3-pentanediol diisobutyrate (TXIB). Both plasticizers exhibited characteristic $\mathrm{C}=\mathrm{O}$ bond stretching around $1725 \mathrm{~cm}^{-1}$. For quantification, the concentration of DEHP was determined from a band characteristic for C-H stretching at $2860 \mathrm{~cm}^{-}$ ${ }^{1}$, while the concentration of PVC was determined from a band attributed to $\mathrm{CH}_{2}$ wagging at $1426 \mathrm{~cm}^{-1}$. The total DEHP concentration of samples was determined by Soxhlet extraction in diisopropyl ether. The results revealed that samples with different bulk concentrations had different surface concentrations.

Samples of PVC tube containing 45 wt.\% DEHP were immersed in hexane. The tube was analysed by attenuated-total reflection (ATR) FTIR spectroscopy, which showed that DEHP was removed from the surface. ${ }^{56}$ In addition, X-ray photoelectron spectroscopy (XPS) was used to determine characteristic bands in plasticized PVC and to monitor $\mathrm{C}, \mathrm{Cl}$ and $\mathrm{O}$ ratios consistent with the removal of DEHP from PVC tube samples. The outermost surface of PVC tubing was free from plasticizer after $6 \mathrm{~min}$ of immersion in hexane.

Internal plasticization of PVC can supress the migration of the plasticizer. In one example, PVC was internally 
plasticized with aminated tung oil methyl ester and exhibited no migration of plasticizer. ${ }^{68}$ The drawback is that such PVC material is thermally less stable than pure PVC In a different study, di(2-ethylhexyl) 4-mercaptophthalate and di(2-ethylhexyl) 5-mercaptoisophthalate had been prepared an internal plasticizers and were used to substitute chlorine in the PVC chain. ${ }^{69}$ Therefore, the migration was stopped entirely and no loss of plasticizer was observed by extraction with heptane in $5 \mathrm{~h}$ at room temperature. In addition, although the plasticizing efficiency was decreased when compared to conventional DEHP plasticizer, glass-transition temperatures below room temperature could be reached at higher concentrations of plasticizer. A simpler approach by using a one-pot procedure from trichlorotriazine was used to modify PVC by chlorine substitution. A wide range of glass-transition temperatures were achieved by modification, where long-chain ethers reached the lowest values. Other approaches such as crosslinking and surface grafting have been examined and found to be lacking in thermal stability. ${ }^{70,71}$

Further studies on plasticizer migration, plasticizer degradation and the influence of plasticizer degradation products on the degradation of PVC at room temperatures are needed. The migration of phthalate plasticizer had been observed by FTIR spectroscopy and XPS by observing the surface of PVC objects before and after exposure to different conditions that promote the migration. There seems to be an acute lack of systematic research on the conditions needed for plasticizers to accumulate on the surface of PVC, leading to conservation issues related to cleaning of sticky surfaces.

\section{PVC Degradation Pathways}

The carbon - chlorine bond in PVC is the principal source of its thermal instability. Due to naturally occurring irregularities in chain structure (such as tertiary or allylic chlorine atom positions) $\mathrm{PVC}$ is prone to elimination of $\mathrm{HCl}$ (Figure 4). An additional allylic chlorine is formed in the polymer chain, that is prone to further elimination, making it an autocatalytic process described in detail elsewhere. ${ }^{72,73}$ Continuous removal of released $\mathrm{HCl}$ in vacuum can decrease the initial rate of PVC degradation considerably. ${ }^{74}$ Due to $\mathrm{HCl}$ elimination, a polyene segment is formed in the PVC chain (Figure 4). When 7-11 conjugated bonds are formed, the absorption peak shifts from UV to visible region which is the reason why degraded PVC objects progressively appear yellow, orange, red, dark brown and then black. Conjugated $\mathrm{C}=\mathrm{C}$ bonds have characteristic IR bands in the range $1585-1625 \mathrm{~cm}^{-1}$.

\section{1. Thermal Degradation of PVC}

The seemingly simple elimination process of hydrogen choride becomes quite complex once we attempt to

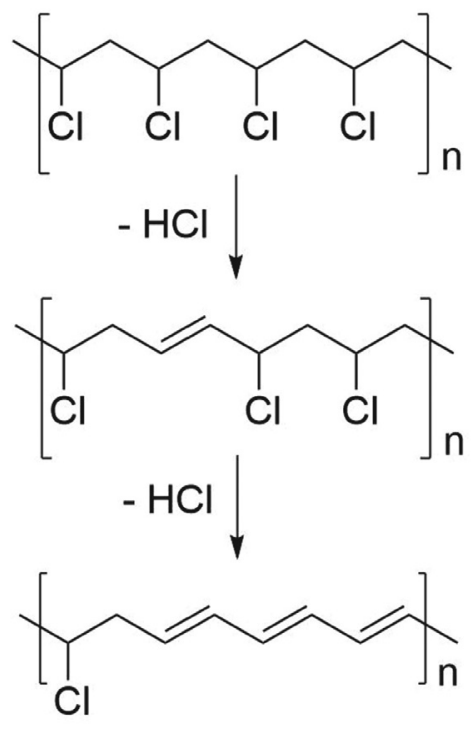

Figure 4: Scheme of elimination of $\mathrm{HCl}$ from PVC.

determine at which labile structures the elimination of $\mathrm{HCl}$ begins, how these structures are formed, what the mechanism of propagation of polyene formation is and how elimination of $\mathrm{HCl}$ is terminated. The initial structural irregularities in the PVC chain form during polymer synthesis. Some characteristic unstable structures, such as allylic chloride, tertiary chloride, carbonyl allyl and head-to-head structures have been considered as possible initiation sites for $\mathrm{HCl}$ elimination and are explained in detail elsewhere. ${ }^{14}$ Most researchers describe allylic chloride and tertiary chloride as the most important sites for thermal elimination of $\mathrm{HCl}^{74-76}$ Allylic chloride can be formed in head-to-head chain growth followed by addition of vinyl chloride monomer, 1,2-chlorine shift and chain-transfer reactions. ${ }^{14,77}$ This amounts to an average value of one initial double bond per PVC chain which was confirmed with NMR studies. $^{14}$

Tertiary chlorides occur at branching points in PVC chains. These can be formed by hydrogen abstraction and reactions with vinyl chloride monomers. An $n$-butyl branch is considered as the main structure containing chlorine bonded to a tertiary carbon. It can be formed by two additions of vinyl chloride monomer, which was confirmed by a ${ }^{13} \mathrm{C}$ NMR study of PVC dechlorinated with $\mathrm{Bu}_{3} \mathrm{SnD} .{ }^{14}$ In ordinary conditions, the concentration of a butyl branch is $1.0-2.4$ per thousand monomer units. Starnes et al. have proposed an equation predicting butyl branch concentration in polymers from the temperature and average monomer concentration during polymerization. ${ }^{78}$ Certain branch points, such as ethyl branch are stable moieties present in commercial resins. ${ }^{79}$

Thermal elimination of $\mathrm{HCl}$ at allylic and tertiary chlorides proceeds in an ionic or quasi-ionic manner. ${ }^{80-82}$ According to Bacaloglu, the elimination of $\mathrm{HCl}$ occurs in a single step, via a four-centre transition state (Figure 5). ${ }^{83,84}$ 


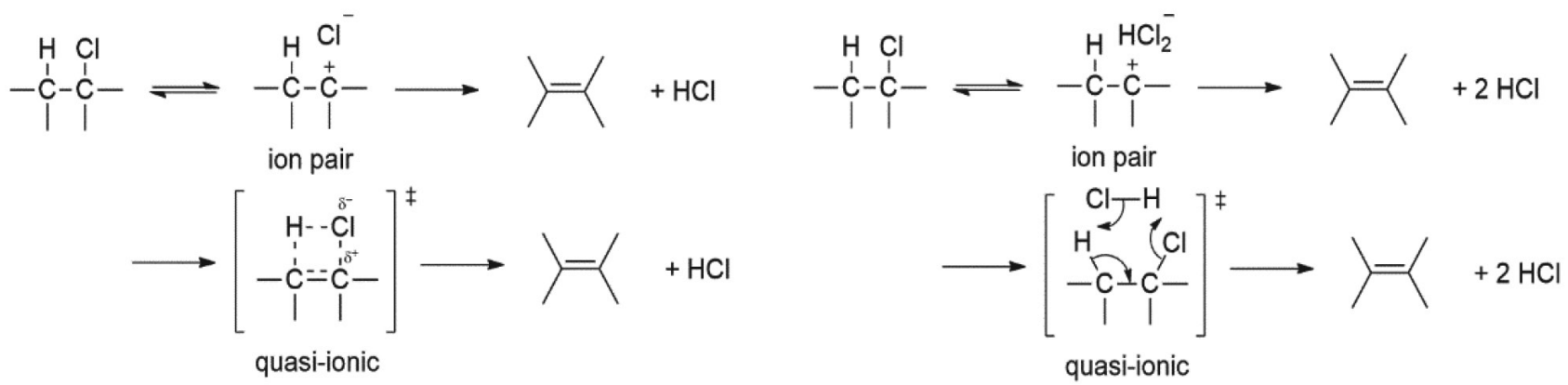

Figure 5: Elimination (the left schemes) and autocatalytic elimination (the right schemes) of $\mathrm{HCl}$ by an ion pair and quasi-ionic mechanism. Adapted from literature ${ }^{14}$.

The evidence for the ionic manner of elimination of $\mathrm{HCl}$ at allylic and tertiary chlorides was gathered from determination of reaction rates of model compounds taking into account their structure and reaction conditions. ${ }^{76}$ The $\mathrm{C}-\mathrm{Cl}$ bond energy of allylic chlorides is $58 \mathrm{kcal} / \mathrm{mol}$, while the bond energy of a tertiary chloride is $67 \mathrm{kcal} / \mathrm{mol} .^{85} \mathrm{In}$ vestigation of reaction rates of allylic and tertiary chlorides at different concentrations of $\mathrm{HCl}$ demonstrated that allylic chlorides are more susceptible to $\mathrm{HCl}$ catalysis than tertiary chlorides, but the elimination of $\mathrm{HCl}$ from tertiary chlorides occurs at a higher rate than that of allylic chlorides at low concentrations of $\mathrm{HCl}^{86}$ The rate of $\mathrm{HCl}$ elimination increased linearly with the concentration of tertiary chlorides in PVC but had no correlation with the concentration of allylic sites. ${ }^{87}$ Additionally, the ionic mechanism is supported by the increase of reaction rates with increasing solvent polarity. ${ }^{88}$ During thermal reprocessing of waste polymer conjugated double bonds are formed, which further decreases the thermal stability. ${ }^{89}$

Bacaloglu and Fisch were investigating the degradation of unplasticized PVC by TGA, ${ }^{1} \mathrm{H}-\mathrm{NMR},{ }^{13} \mathrm{C}$ NMR and $\mathrm{UV} /$ Vis spectroscopy ${ }^{83}$ Elimination of $\mathrm{HCl}$ was confirmed to be the main degradation pathway for temperatures up to $200{ }^{\circ} \mathrm{C}$. Condensation of double bonds and crosslinking were only minor processes. Elimination of $\mathrm{HCl}$ was monitored continuously with a conductivity cell and proceeded as a two-stage process. First, a faster elimination of $\mathrm{HCl}$ occurred from structural irregularities (allylic and tertiary chlorine) with a lower activation energy for conversions under $0.1 \%$. When those were exhausted, elimination of $\mathrm{HCl}$ occurred at random from regular monomer structural segments with up to $2-3 \%$ conversion. ${ }^{83}$ Structural irregularities were found to be significant only for low conversions and the majority of $\mathrm{HCl}$ elimination occurred randomly from regular monomer units. UV/Vis spectra of PVC in THF analysed with empirical equations revealed that relatively short polyenes $(\mathrm{n}<8)$ are the most common and the longest polyene was 25-30 double bonds long.

Simultaneous measurements of $\mathrm{HCl}$ emission by conductometry and the formation of polyenes by Raman spectroscopy were performed for the degradation studies of PVC films at $171^{\circ} \mathrm{C} .{ }^{90}$ A polyene with 14 conjugated double bonds represented the formation of long polyene sequences and was chosen by selecting wavelength of Raman excitation. It was shown that the number of polyenes $\mathrm{n}=14$ rapidly increased in the first $30 \mathrm{~min}$, while the emission of $\mathrm{HCl}$ continued. At a degradation level of $0.1 \% \mathrm{HCl}$ elimination, the number of polyenes $n=14$ reached a plateau value. The value was lower at higher degradation temperatures and higher oxygen pressure. During cooling, the number of polyenes doubled but no additional $\mathrm{HCl}$ was emitted. This suggested that longer polyenes may undergo consecutive reactions, oxidize or cross-link.

Other structures and mechanism have been proposed as possible reasons for PVC instability. Some research concluded that carbonyl allyls are responsible for the degradation of PVC by forming furanoid moieties. ${ }^{91}$ There is no strong evidence for the presence of such structures in commercial PVC. The degradation of PVC involves free radicals, as shown by ESR spectroscopy. ${ }^{92}$ The initial elimination of $\mathrm{HCl}$ does not proceed via a radical mechanism due to non-selective reactivity of a chlorine radical in hydrogen abstraction and high concentration of non-allylic hydrogens. The detected radicals are most likely degradation products. When the degradation reaches a point with sufficient levels of polyenes and $\mathrm{HCl}$, polyenyl cation radicals are formed. They degrade autocatalytically by abstraction of a methylene hydrogen and $\beta$-scission to form new allylic chloride initiation sites. ${ }^{15}$ A source of these radicals may be a residual initiator or excitation of polyenes. A six-centre mechanism involving isomerization and elimination of $\mathrm{HCl}$ from cis chloroallyl structures has been proposed by Bacaloglu but Starnes thought it improbable due to slow isomerization of allyl chlorides as shown in a reactivity study of model compounds. ${ }^{83}$ Termination of continuous dehydrochlorination may include cyclization, leading to the formation of aromatic compounds and monoalkylcyclopentane structures, detectable by ${ }^{13} \mathrm{C}$ NMR. $.14,77$

\section{1. 1. Influence of Isomerism and Crystallinity}

Additionally, isomerism of PVC influences the mechanism of its degradation. A polymer can be organ- 
ised into three configurational structures: isotactic, where all chlorine atoms are on the same side of the chain; syndiotactic, where the positions of chlorine atoms alternate; and atactic, where chlorine atoms are distributed randomly. The lower is the processing temperature of PVC formation, the higher is amount of syndiotactic sequences. Among these, the atactic form of PVC is amorphous, while isotactic and syndiotactic forms can crystallize. The syndiotactic sequences are usually short but enable strong forces between chains to induce crystallinity. They are also thought to cause the antiplasticization effect. ${ }^{93}$ Bonding amongst chains is increased in syndiotactic segments, so free volume and chain mobility are decreased. Initially, it was thought that syndiotacticity increases the dehydrochlorination rate, but it was proven that tacticity does not directly affect dehydrochlorination. ${ }^{94}$ Commercial PVC, polymerized at $50{ }^{\circ} \mathrm{C}$, has about $30 \%$ syndiotactic sequences, that are 5-6 units long and around 5-10\% crystallinity $^{95}$, so the majority of PVC objects in heritage collections are likely similar.

Chain length, branching, chain folding, and chain entanglement affect polymer properties, such as viscosity and shape memory, UV and thermal stability by affecting the crystallinity of the material. Chartoff identified three IR bands in the $\mathrm{C}-\mathrm{Cl}$ stretching region, specifically 610(615), 635 and $690 \mathrm{~cm}^{-1}$ as useful for indicating crystallinity and the ratio of $\mathrm{A}_{635} / \mathrm{A}_{610}$ was used for determination of crystallinity. ${ }^{96}$ In more recent studies, bands at 604, 635 and $1427 \mathrm{~cm}^{-1}$ are considered to represent crystalline regions while bands at 615 and $1435 \mathrm{~cm}^{-1}$ are considered to represent amorphous regions. ${ }^{97-99}$

The presence of crystalline regions in the material can be observed by DSC as a sharp endothermic peak at temperatures $100-200{ }^{\circ} \mathrm{C}$. Crystallinity affected the physical degradation of PVC. ${ }^{100}$ The influence of plasticization on crystallinity is not clear. ${ }^{101,102}$ It is believed that degradation at temperatures below the Tg affects only the amorphous regions. ${ }^{103}$ Some studies show that the degree of crystallinity decreases with increasing plasticizer content. ${ }^{104}$ Other studies imply that plasticizer does not change the crystalline domains because it cannot penetrate them and does not affect the crystallinity of the material. ${ }^{105}$ The crystallinity regions in the material are dependent on the plastic's thermal history. During annealing the material is heated to elevated temperatures and cooled down to reduce moulded stress.

Heating and cooling rates influence the crystallinity of the material as slower cooling allows more time for PVC chains to reach an equilibrium state and crystallize. A study investigated the effect of thermal degradation temperature on the melting temperature of crystalline PVC in plasticized PVC. ${ }^{106}$ The degradation was carried out at different temperatures below $\operatorname{Tg}\left(23,40,60^{\circ} \mathrm{C}\right)$ or at $100^{\circ} \mathrm{C}$ for up to 45 days. The melting temperature of crystalline PVC (a sharp endothermal peak at $100-200{ }^{\circ} \mathrm{C}$ ) was observed after only 7 days of degradation at $40^{\circ} \mathrm{C}$ and
$60{ }^{\circ} \mathrm{C}$, but not for degradation at $23{ }^{\circ} \mathrm{C}$ nor $100{ }^{\circ} \mathrm{C}$. The melting temperature was increasing with the degradation time for degradation at $40{ }^{\circ} \mathrm{C}$ and $60{ }^{\circ} \mathrm{C}$. This indicates that exposure to elevated temperature below $\mathrm{Tg}$ allows the chains in the amorphous region to reorganize and form crystalline domains, but the process is generally slow. Degradation above $100^{\circ} \mathrm{C}$ is already in the region of melting crystalline PVC. The higher degree of crystallinity reduces the free volume and increases the specific density of the material.

Elimination of $\mathrm{HCl}$ creates sequences of polyenes, which may be subjected to geometrical cis-trans isomerism. The degradation of PVC by elimination of $\mathrm{HCl}$ leads to the eventual formation of all-trans polyenes. ${ }^{107}$ In general, the trans form is thermally more stable than the cis form. A spectrophotometric investigation of cis/trans isomers of polyacetylene revealed that the trans form is red in colour, while the cis form is blue. ${ }^{108,109}$ The degraded PVC first turns yellow and then red and brown, which is in agreement with the characteristic red colour of the trans form. The degraded all-trans isomer becomes more rigid and less flexible.

\section{1. 2. Impact of Heat Stabilizers and Object Geometry}

Barium, calcium, cadmium and zinc salts of longchain aliphatic acids, such as stearates, are commonly used as heat stabilizers in PVC material. ${ }^{98,110}$ Organotin compounds and lead salts were historically used in great extent. ${ }^{1,111}$ Heat stabilizers react with $\mathrm{HCl}$ and form metal chlorides. Calcium, barium and other alkaline metals form stable chloride salts, that do not accelerate the degradation of PVC even in the form of partially reacted calcium or barium stearates. ${ }^{112}$ On the contrary, stearates of aluminium, cadmium, zinc and antimony were found to accelerate the elimination of hydrogen chloride. ${ }^{113-115}$ Tin stabilizers can help reduce the rate of elimination by additionally forming stabilizing coordination complexes and chlorine exchange reactions ${ }^{116}$, but $\mathrm{SnCl}_{4}$ and $\mathrm{RSnCl}_{3}$ were found to increase the elimination rate and cause the material to fail. ${ }^{111}$

It was demonstrated that the rate of $\mathrm{HCl}$ elimination decreases with an increase in the surface-area-to-volume ratio, because diffusion of the evolved $\mathrm{HCl}$ reduces its concentration in the polymer, and surface degradation is no more intensive than in the bulk. ${ }^{72}$ PVC films of varying thicknesses were prepared and exposed to temperatures $150-190{ }^{\circ} \mathrm{C}$. The $\mathrm{HCl}$ produced takes longer to diffuse through thicker samples, so that the dehydrochlorination rates are higher due to more effective autocatalysis. It was shown that the dehydrochlorination rate of previously degraded samples increased. The study was carried out at high temperatures, and it remains to be seen whether the observed increase of degradation in thicker samples is also valid for degradation at room temperatures. 


\section{1. 3. Consequences of Thermal Degradation}

Thermal degradation of plasticized PVC results in the emission of plasticizer and elimination of $\mathrm{HCl}$. These processes do not occur in the same timeframes as is graphically presented in the Figure 6. The emissions of plasticiser are intensive immediately after the production of PVC and then remain more or less constant (depending on storage conditions). Degradation is not directly related only to the intensity of dehydrochlorination as suggested by the studies described in the previous Sections. Elimination of $\mathrm{HCl}$ gradually increases as new dehydrochlorination sites form, and reaches a maximum. During advanced stages of degradation the chlorine sites become exhausted and production rates of $\mathrm{HCl}$ decrease.

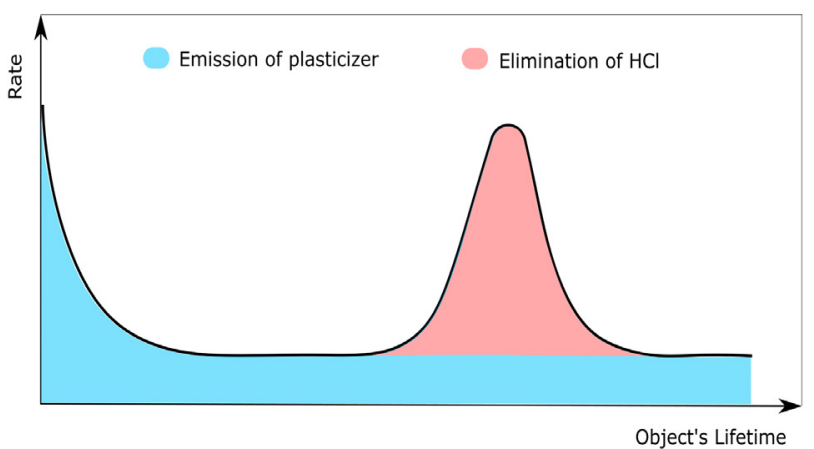

Figure 6: A schematic presentation of hypothetical emission and elimination rates during the lifetime of a PVC object.

Although experiments at elevated temperatures suggest that $\mathrm{HCl}$ evaporates from the material, it is not clear if this is significant at temperatures close to room temperatures. PVC has some affinity for water and may absorb up to $1 \%$ of water upon immersion. ${ }^{117}$ With at least some water present in the material it is therefore possible to assume that $\mathrm{HCl}$, being a strong acid, is mostly dissociated, or that weak acids are preferentially protonated and emitted from the material, e.g. plasticizer degradation products. This could explain why elimination of $\mathrm{HCl}$ has not yet been observed at room temperatures and may not be a significant conservation risk, as further discussed in Section 4.2. However, more research is needed to understand these processes better.

\section{2. Mechanical Instability of PVC}

Plastic structures are exposed to continuous stress at joints, beams and hanging supports. Plastics under constant stress eventually permanently deform, which is described as creep deformation. Even if such stress is below the yield-point, localized molecular disentanglement can occur at stress-points. ${ }^{118}$ Time and temperature act similarly and can lead to creep rapture as brittle or ductile failure. The time of failure can be predicted with dynamic mechanical analysis based on time-temperature equivalency. ${ }^{119}$
The effect of pollutants such as ozone, nitrous oxides and hydrocarbons on the degradation of PVC was also studied. ${ }^{120}$ Exposure to atmospheric ozone for 15 months caused the biggest deteriorating effect. Initially, oxidation products were observed on the surface of samples with FTIR and UV/Vis spectroscopy, but the samples still retained their hardness. Further exposure to ozone caused chain scission and accelerated the elimination of $\mathrm{HCl}$ and formation of polyene sequences. The effect of $\mathrm{NO}$ and $\mathrm{NO}_{2}$ was not as pronounced.

Ito and Nagai studied the degradation of plasticized PVC under accelerated degradation conditions. ${ }^{121}$ PVC sheets were prepared by blending PVC with DEHP, carbon black, $\mathrm{CaCO}_{3}$ and a stabilizer and moulding to $1 \mathrm{~mm}$ sheets. Weathering using exposure to xenon light, cyclic spraying with distilled water at elevated temperature of $63{ }^{\circ} \mathrm{C}$, as well as thermal degradation (at $100^{\circ} \mathrm{C}$ in a ventilated oven) were used. Degradation was followed by measuring mechanical properties (tensile strength and dynamic properties), SEC, pulsed NMR and DEHP content. The number average molecular weight $M_{n}$ did not change under weathering conditions nor under thermal degradation. At weathering conditions, some inorganic additives were removed from the surface, creating voids that were visible under a microscope. Plasticizer concentration was determined by Soxhlet extraction and GC-MS analysis. A higher loss of plasticizer content was observed in the weathering test than during thermal degradation due to the plasticizer being washed out during spraying cycles. The decrease of DEHP content during the thermal degradation conditions was due to evaporation.

Some studies of PVC degradation involve SEC. Loss of mechanical properties of 10-year-old PVC exposed to sunlight was evaluated. ${ }^{122}$ SEC measurements showed an obvious decrease of the weight average molecular weight $M_{w}$ from $M_{w}=91.702 \mathrm{~g} / \mathrm{mol}$ and the polydispersity index, given as the ratio $M_{w} / M_{n}, M_{w} / M_{n}=2.27$ for the reference PVC to $M_{w}=13.847 \mathrm{~g} / \mathrm{mol}$ and $M_{w} / M_{n}=15.7$ for the degraded PVC. A study of high-dose gamma radiolysis of PVC showed a strong decrease in molecular weight of PVC dissolved in THF, reported as polystyrene equivalent. $^{123}$

\section{3. Photodegradation of PVC}

Thermal elimination of $\mathrm{HCl}$ and plasticizer migration are the major degradation pathways for PVC kept indoors at room temperature, although it may also degrade due to oxidation ${ }^{124}$, photooxidation ${ }^{125,126}$, or radiolysis ${ }^{123}$. Objects used outdoors are exposed to UV light causing photooxidation. Such degradation may not be directly relevant to degradation in museums, but understanding it is useful for preventing further damage.

Although the PVC structure contains C-H, C-C and $\mathrm{C}-\mathrm{Cl}$ bonds, which are too strong to be broken directly, it is known that PVC does degrade on exposure to sun- 
light. ${ }^{127}$ Absorption of UV radiation can occur due to chromophore impurities (carbonyl groups), presence of sensitizers (benzophenones, hydroquinone, ...), organometallic compounds, thermal stabilizers forming metal chlorides, metal oxides $\left(\mathrm{TiO}_{2}, \mathrm{Al}_{2} \mathrm{O}_{3}\right)$, and fillers. ${ }^{128} \mathrm{Impu}-$ rities catalyse photodegradation by forming radicals. Photooxidation causes the formation of conjugated double bonds, carbonyl compounds, and chain scission. ${ }^{129}$ Monochromatic radiation was used to study the changes in absorption of rigid PVC from $280 \mathrm{~nm}$ to $500 \mathrm{~nm} .{ }^{130}$ It was shown that the sensitivity of PVC decreases with increasing wavelength. Wavelengths from $280 \mathrm{~nm}$ to $340 \mathrm{~nm}$ caused the samples to become yellow, but irradiation at $400 \mathrm{~nm}$ and $500 \mathrm{~nm}$ had a photobleaching effect. ${ }^{131}$ Photooxidation causes short polyenes to form, which absorb light at wavelength below $400 \mathrm{~nm}$. Exposure to sunlight caused yellowing to appear with a delay, if the objects were stored in the dark after irradiation. Short polyene segments underwent thermal isomerization and started to absorb wavelengths above $400 \mathrm{~nm}$, giving them a yellow appearance. By exposing them to $400 / 500 \mathrm{~nm}$, yellowing reversed as the polyene segments isomerized. Higher pressure of oxygen promotes oxidation which causes ozonolysis of double bonds with no yellowing. This is observed in older PVC formulation, but PVC intended for outdoor use contains $\mathrm{TiO}_{2}$, which prominently decreases yellowing. ${ }^{132}$

\section{Properties Relevant to Conservation}

Research investigating the properties of PVC objects relevant to conservation has been organized in three subsections. Firstly, studies on the topic of colour change of PVC objects during ageing are discussed. Secondly, studies of emissions of hydrogen chloride and volatile organic compounds relevant to the conservation of heritage collections are gathered. Lastly, studies encompassing a broader variety of analytical techniques investigating natural and accelerated degradation are presented.

\section{1. Colour}

The most common method for the determination of apparent colour change of objects is spectrocolorimetry. Colour coordinates using CIELab, XYZ or RGB colour systems can be calculated, either in transmission or reflectance mode. CIELab colour space uses $L^{*}$ for lightness (black to white), $\mathrm{a}^{*}$ for green to red and $\mathrm{b}^{\star}$ for blue to yellow as the three coordinates to describe the perceived colour. It is more perceptually uniform than the XYZ colour space. The difference between two colours (CIELab $\Delta \mathrm{E}_{2000}$ ) can be calculated from the differences in the measured $\mathrm{L}^{*}$, $\mathrm{a}^{\star}, \mathrm{b}^{\star}$ values. In general, $\Delta \mathrm{E}_{2000}=1.5$ is considered $\mathrm{a}$ threshold of perceptible change in colour. ${ }^{133}$

PVC discolouration is related to the formation of conjugated polyene segments in PVC chains. The degrada- tion of PVC is apparent as objects become visibly yellow, brown or in some cases pink (Figure 7), if the formulation contains $\mathrm{TiO}_{2}$ and lead stabilizers. ${ }^{57,59,134,135}$

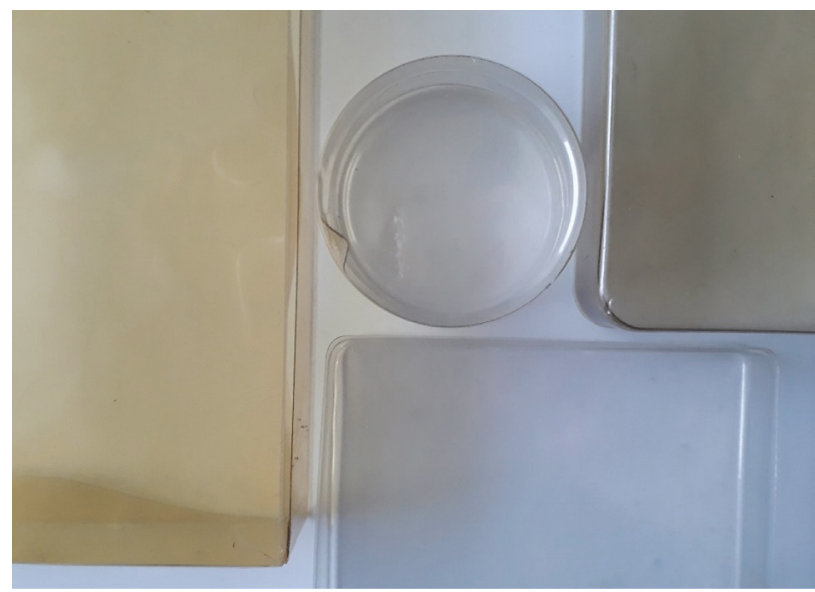

Figure 7: Discolouration of PVC objects.

A systematic approach to examining absorption spectra of polyenes with increasing number of conjugated double bonds $n$ was carried out by Daniels and Rees. ${ }^{136}$ The values for absorption maxima and extinction coefficients were gathered and used as linear combinations to determine an approximate concentration of each polyene in a sample. A visible colouration appears when at least 7 conjugated double bonds are present. Since degradation leads to polyene segments varying in length, the absorption spectra of which contain multiple maxima, the cumulative absorption spectrum is broad. A study of conjugated alkenes with UV/Vis spectroscopy revealed that an average increase in the wavelength of the absorption maximum of $30 \mathrm{~nm}$ per each additional conjugated double bond is observed for up to 6 conjugated double bonds. ${ }^{137}$ The Lewis-Calvin equation is based on empirical data and describes the square of the wavelength of the absorption maximum of polyenes being proportional to the number of conjugated bonds. ${ }^{138}$ Additionally, it has been shown that the extinction coefficient of polyenes increases linearly with $n$. The shape of the absorption spectra is affected by the substituent effect, the solvent effect and cis/trans isomerism. In general, trans isomers absorb at longer wavelengths.

Describing the extent of PVC degradation based on apparent colour change as a simple 'colour scale' was designed in 1971 by Ocskay et al. ${ }^{139}$ The scale had 11 levels and was based only on the darkening of the material evaluated by visual comparison, which is too imprecise and prone to human error for systematic studies of degradation. Hollande and Laurent used spectrophotometry to study the changes in absorption for plasticized and unplasticized PVC films during exposure to UV light. ${ }^{140}$ Pure DOP and PVC films with or without DOP were prepared and degraded under a UV lamp at $50{ }^{\circ} \mathrm{C}$. The 
absorption bands between 250 and $500 \mathrm{~nm}$ kept increasing with exposure time. In addition, it was shown that plasticizer contributes to the increase of absorption and discolouration as well. In a different approach by Wijdekop et al., reflectance spectroscopy was examined as a tool for monitoring colour change of a PVC coated steel strip. ${ }^{141}$ The intensity of $\mathrm{HCl}$ elimination was quantified by calculating the difference in surfaces of spectra taken before and after photodegradation. As the PVC samples continued to darken under UV light, the reflectance across the whole visible region $400-700 \mathrm{~nm}$ kept decreasing.

Apart from using spectroscopy and colour models for investigating changes during degradation, changes in optical density due to darkening are also of interest. Such an approach was used by Shashoua to determine the darkening of model PVC sheets. ${ }^{57} \mathrm{~A}$ blue filter was used to determine yellowing from accelerated degradation. Sheets with lower DEHP concentration exhibited increased yellowing compared to sheets with higher DEHP concentrations. Additionally, the effect of different sorbents on the discolouration was tested. All sorbents had a significant effect on the discolouration. It was observed that silica and active charcoal initiated a more intensive change of colour. ${ }^{57,67}$ It is important to remember that colour change is guided by many simultaneous processes driven by the composition of an item, as well as its exposure to heat, light and pollutants.

Pastorelli et al. investigated the colour change of 17 different polymeric materials at different conditions, with variables such as temperature, relative humidity, concentration of $\mathrm{NO}_{2}$ and ozone being continuously measured. ${ }^{134}$ PCA was used to determine the most important variable. $\mathrm{NO}_{2}$ concentration and exposure to light had the most pronounced effect on discolouration. A previously mentioned study ${ }^{120}$ found ozone to cause the most deterioration. The different conclusions are likely the result of different experimental set-ups. Pastorelli's study was carried out by monitoring the variables in sheltered conditions, while Belhaneche-Bensemra's study compared accelerated ageing to natural ageing at outdoor conditions without shelter.

Different approaches to quantifications of colour change have been used in studies of PVC degradation. Observing the degradation through a colour change is especially useful for objects of heritage value, because the technique is both non-destructive and fast.

\section{2. Emissions}

Headspace analysis is a non-invasive sampling technique that enables identification of characteristic emissions from PVC objects. Hydrogen chloride is the main degradation product of PVC polymer, on the other hand emissions of VOCs are related to used additives, mainly plasticizers.
PVC degradation can be monitored by the determination of the amount of the released volatile $\mathrm{HCl}$. Complete elimination of $\mathrm{HCl}$ would result in $58.3 \%$ mass loss for pure PVC. As a polar volatile compound, $\mathrm{HCl}$, the main degradation product of PVC, can be trapped by silica gel and other molecular sieves, however, these are not suitable for sampling in high relative humidity.

There are different approaches to determination of the formed $\mathrm{HCl}$. The ISO 182 standard prescribes a qualitative method using an oil bath at $180 / 200{ }^{\circ} \mathrm{C}$ to heat the investigated material in a glass tube and collect the acidic emissions on a wetted indicator paper. ${ }^{142}$ This may be useful for identification, although not for objects of heritage value. Another approach is to heat the test material at $180 / 200^{\circ} \mathrm{C}$ in a gas stream to absorb the formed $\mathrm{HCl}$ into a trapping solution. This can be demineralized water for potentiometric measurements or measurements of conductivity.

Most studies of hydrogen chloride emission from PVC have been carried out at high temperatures because such processes are relevant for incineration, pyrolysis and waste management. During this literature review no studies investigating the emission near room temperature were found. It is expected that the rate of dehydrochlorination at low temperatures is orders of magnitude lower than in studies discussed previously. Experimental limitations such as long sampling times and working with concentrations near detection limits occur. Long sampling times can lead to experimental error when using sorbents or liquid traps. Sorbents may contain impurities that make quantification difficult.

The degradation products of plasticizers are usually more volatile and categorized as semi-volatile organic compounds (SVOCs). The emissions of VOCs can be sampled actively or passively by using solid sorbents, e.g. solid phase microextraction (SPME) fibres, or liquid traps. Determination of characteristic VOC emissions from PVC objects is commonly carried out with headspace analysis followed by chromatographic separation, such as GC-MS analysis for the identification and/or quantification.

Determination of VOCs from newly produced commodity PVC is commonly performed in the course of emission testing, e.g. flooring materials and other products. Lundgren et al. determined the total VOC (TVOC) emissions rates from newly manufactured PVC flooring materials using a FLEC cell (Field and Laboratory Emission Cell), as used for emission testing on planar materials and coatings. ${ }^{143}$ New PVC materials released hydrocarbons from pentane to octadecane, 2-(2-butoxyethoxy)ethanol, butoxyethanol, cyclohexanone, 2-ethylhexanol, 2-ethoxyhexanol, 2-ethylhexanoic acid, phenol, trimethylbenezene, diethylbenzene, toluene and $\mathrm{N}$-methyl-2-pyrrolidone. The emission rates of PVC flooring were in the range of $100-500 \mu \mathrm{g} \mathrm{TVOC} / \mathrm{m}^{2} \mathrm{~h}$ after 4 weeks since production and in the range of 50-200 $\mu \mathrm{g}$ TVOC/ $\mathrm{m}^{2} \mathrm{~h}$ after 26 weeks since production. For many flooring 
materials, the emission rate decreased to less than half in 4 to 26 weeks following production.

Carlsson et al. have exposed PVC to accelerated UV degradation. ${ }^{144}$ Volatiles released during and after the experiment were identified. Using SEC, a decrease in the average molar mass of PVC was determined during the experiment, while the volatiles were collected on a series of two thermal desorption tubes. The first tube was packed with Carbotrap and the second one with Carbosieve S. The powdered samples were placed into Pyrex tubes and inserted into a modified inlet system at 80 (or 120) ${ }^{\circ} \mathrm{C}$ for 1 (or 3) min to desorb volatile compounds remaining after UV irradiation. Butan-1-ol, di-butyl ether and methyl methacrylate were present in non-degraded samples while UV exposure led to the formation of various chlorinated species, such as 1-chlorobutane, 1,2-dichlorobutane, 1-chloropentane and 1,1-dichloropropan-2-one. The obtained results were in accordance with investigations on outdoor-weathered PVC surfaces. The released $\mathrm{HCl}$ was continuously monitored using a conductivity cell and gravimetric determination after precipitation with $\mathrm{AgNO}_{3}$. XPS analysis of the surface revealed that degraded samples were highly oxidised, with elevated oxygen and deficient chlorine levels.

VOCs released from a general collection of heritage plastics have been examined to determine their effect on the stability of other heritage objects by Mitchell et al. in 2013. ${ }^{145}$ VOC and SVOC were collected from plastic objects using a micro-chamber/thermal extractor at $23^{\circ} \mathrm{C}$ or $70{ }^{\circ} \mathrm{C}$ for $1 \mathrm{~h}$ to Tenax TA tubes and analysed using thermal desorption in combination with GC-MS (TD-GCMS). The emissions from PVC samples at $23{ }^{\circ} \mathrm{C}$ were non-specific VOCs, present in many polymers and were not suitable to distinguish PVC from other plastics: dibutylhydroxytoluene, decanal, nonanal, benzaldehyde, styrene, 1,3-dimethylbenzene, ethylbenzene, TXIB plasticizer and diethyl hexanolacetophenone. After heating to $70{ }^{\circ} \mathrm{C}$, the emissions were more intensive and benzene, toluene, nonanal, nananoic acid, decanal, decanoic acid and isopropylbenzene were detected in addition.

A study of VOCs from PVC films by headspace SPME-GC-MS identified 2-ethylhexanole, nonanal, hexanal, heptanal, $\mathrm{m}$-xylene and chlorobutane as the main compounds. ${ }^{146}$ Plasticized PVC sheets were heated and the emitted VOCs were trapped by Tenax GR sorbent before analysis by GC-MS to identify phenol, 2-ethylhexanol, octadecene, triphenyl phosphate and DEHP. ${ }^{147}$

A study by Curran et al. used VOC analysis to classify museum artefacts by type and extent of degradation. ${ }^{148}$ SPME GC-MS analysis of samples made of PVC and other plastics found in collections was carried out following degradation at $80{ }^{\circ} \mathrm{C}$ and $65 \%$ relative humidity for up to 10 weeks. 2-ethylhexanol emission from PVC samples was shown to increase up to two weeks into the process of accelerated degradation and remained at that level for the following 8 weeks.

\section{3. Survey of PVC Degradation in Heritage Collections}

Historic polymeric samples from a private collection were analysed by ATR-FTIR spectroscopy and identified successfully by band assignment, a suitable method for characterizing unknown polymers in heritage collections. Principal component analysis (PCA) was tested to classify unknown samples with moderate success. ${ }^{149}$ Cellulose acetate, cellulose nitrate, polycarbonate and polyurethane foam samples were successfully recognised, while polystyrene, rubber, polyvinyl chloride, polyethylene and polypropylene were not. Terahertz time-domain spectroscopy (THz-TDS) is a novel spectroscopic technique that was used for characterization of historic plastics. ${ }^{150} \mathrm{THz}$-TDS spectra could reflect long-chain vibrations and vary for different polymers but exhibited no features immediately useful for identification. THz-TDS could also not be used to detect plasticizers in PVC.

A study of PVC degradation included accelerated degradation and comparison of possible conservation methods for storage of PVC objects. ${ }^{67}$ PVC model sheets were kept in different environments and degraded for 65 days at $70{ }^{\circ} \mathrm{C}$, after which the mass loss was examined. ${ }^{57}$ The mass loss was attributed to loss of DEHP plasticizer. The least amount of mass loss was observed in sheets degraded at high relative humidity, in a freezer at $-20^{\circ} \mathrm{C}$ or in a closed environment. It is possible that mass loss by accelerated degradation in high-humidity was deceivingly low due to simultaneous water uptake and DEHP loss, since studies have shown that DEHP loss is independent from humidity. ${ }^{51,61}$ The highest loss of mass was observed when PVC sheets were degraded in an open environment or stored in LDPE bags, which are capable of absorbing DEHP from PVC sheets, making them observably stiffer. The highest DEHP loss was observed in the first 7-10 days of accelerated degradation in open environment and 14 days in closed environments. Accelerated degradation at high relative humidity environment caused the sheets to turn opaque. After returning them to normal conditions, the transparency was mostly recovered. No change in optical density was observed for degradation in a closed environment. Discolouration occurred during degradation in the presence of sorbents and for samples stored in a LDPE bag, and was the highest for sheets with lower concentrations of DEHP. Degradation with silica gel or activated carbon in the closed container led to higher discolouration and development of darker spots on the sheets. Low-vacuum SEM mapping of chlorine and oxygen allowed visualisation of PVC and DEHP on sheets. It appeared that a thin DEHP layer was present on all model sheets containing more than 33 wt. \% of DEHP by bulk. Sheets with lower bulk concentrations were homogenous in composition.

An investigation into cold storage revealed that while the rate of chemical degradation (elimination of $\mathrm{HCl}$ ) is reduced, physical change, such as shrinking and brittle- 
ness may lead to degradation if the process of cooling is too rapid. ${ }^{151}$ Gradual cooling and heating are essential to avoid degradation. In another study, dolls made of plasticized PVC were kept in cold museum storage for 10 years, with the average temperature of $11^{\circ} \mathrm{C}$ and temperatures ranging from $7{ }^{\circ} \mathrm{C}$ to $16^{\circ} \mathrm{C}$ during the year. After inspection, the dolls appeared to have a white waxy substance covering their plastic parts. ${ }^{152}$ The bloom was identified as stearyl alcohol by ATR-FTIR, which is not a common additive for plasticized PVC. It was independent of the plasticizer and exuded due to reduced compatibility with PVC at low temperatures. The stearyl alcohol was reabsorbed into the dolls after keeping them at room temperature.

Yellowing and surface cracking of PVC due to photooxidation was investigated with spectrocolorimetry and microscopy. ${ }^{153}$ During the degradation, PVC turned darker and more yellow. In addition, the scratch hardness of degraded PVC increased while indentation hardness had decreased according to micro- and nanoindentation tests. The indentation hardness may have decreased due to chemical changes in additives, such as the reaction of calcium carbonate with hydrochloric acid. Micro-scratching is relevant for assessing possible damages during an object's transportation. FTIR spectroscopy revealed that hydroperoxides and polyenes are formed during the photooxidation. This was in line with the observed surface embrittlement.

A more recent study by Royaux showed that the loss of plasticizer and yellowing of PVC can be slowed down significantly by keeping the item in a closed container, as demonstrated with TGA and ATR-FTIR measurements. ${ }^{59}$ 30-year-old PVC samples, stored at museum conditions, were investigated. Accelerated degradation was carried out in a temperature cycle of $80^{\circ} \mathrm{C}$ for 2 days and $25^{\circ} \mathrm{C}$ for 1 day at $65 \%$ relative humidity in open and closed containers. Yellowing was measured as $\Delta \mathrm{b}^{*}$ and reached values of 10 and 14, after 12 weeks of degradation in closed and open environment, respectively. Degradation was also noticeable as an increase of absorbance by UV/Vis spectroscopy but ATR-FTIR could not be used to detect any changes. The study found that plasticizer migration proceeded in a diffusion-controlled manner. In addition, surface cleaning and removal of exuded plasticizer had no negative effect on the kinetics of PVC degradation, retaining its appearance.

A study compared naturally degraded 15- to 30-year old PVC samples to degradation in locations with hot or cold environment with accelerated photooxidative degradation. ${ }^{154}$ TGA was used to determine the plasticizer content of samples by measuring the weight loss at $400{ }^{\circ} \mathrm{C}$. The mass loss until $400{ }^{\circ} \mathrm{C}$, due to the loss of DEHP plasticizer and dehydrochlorination, can be used for calibration to determine the plasticizer content of unknown PVC samples. Loss of plasticizer was found to be the main process for naturally degraded samples. An increase of porosity was observed as well. Upon exposure to water, lead salts were released from the cables. Photooxidative degradation was observed as an increase in absorption at $1720 \mathrm{~cm}^{-1}$ by IR spectroscopy. Accelerated degradation at $140^{\circ} \mathrm{C}$ resulted in an increase of the molecular weight due to cross-linking reactions. The authors concluded that the exposure to different outdoor environments and conditions of use significantly affected PVC's properties, so there was no point in having a general kinetic equation describing the differentdegradation mechanisms.

The cross-infection effect of historic and heritage polymer artefacts was tested by measuring the degradation of cellulose reference test material. ${ }^{29}$ Degrading polymers emit compounds, such as acetic acid from cellulose acetate ${ }^{155}, \mathrm{NO}_{2}$ from cellulose nitrate ${ }^{156}$ and as often assumed, $\mathrm{HCl}$ from PVC, and these may cause degradation of materials kept nearby. The cross-infection effect of 14 polymer types was tested by exposing them to a reference paper of pure cellulose in a sealed vessel for 14 days at $80^{\circ} \mathrm{C}$. After the exposure, the impact of VOC emissions was determined by the change of the degree of polymerisation of cellulose. The headspace above plastic samples was also investigated by SPME-GC-MS analyses. Cellulose nitrate exhibited the most severe cross-infection effect, followed by specific samples of cellulose acetate, polyvinyl chloride and polyvinyl acetate copolymer, polyethylene and polypropylene. Polyvinyl chloride, polymethylmethacrylate and phenol formaldehyde had a neutral cross-infection effect. The main emissions of PVC were found to be 2-ethylhexanol, 2-ethyl acetate, 2-ethyl hexanal, methyl methacrylate and butyl 2-methyl-2-propenoate, which are degradation products of commonly used plasticizers, however, potential emissions of $\mathrm{HCl}$ were not measured.

Plastics are also popular construction materials for display cases, storage and transportation in museums. Oddy testing is an established method for evaluating the suitability of materials used in museums to assess risks to objects in collections due to emissions of VOC from materials on selected metals: silver, lead and copper. ${ }^{157,158}$ Evolved gas analysis (EGA) coupled to GC-MS was used to detect VOC emitted from common polymeric materials. ${ }^{159}$ 3-Nonene, p-ethyltoluene, a-methylstyrene, 2,3,6,7-tetramethyloctane, 2,6-dimethyloctane, 5-ethyl-2,2,3-trimethylheptane and 2-phenyl isopropanol were emitted from PVC powder. Plasticized PVC is generally not recommended for use in museums due to migration of plasticizer and $\mathrm{HCl}$ emission. Rigid unplasticized PVC boards, sometimes used in construction of gallery cases, pass the Oddy test as no signs of corrosion on metals are observed. ${ }^{160}$ The previously-described study of cross-infection effect is in agreement with these results. EGA-GC-MS was proposed as a fast alternative to Oddy testing. The analysis reported the emission of 2-ethyhexanol, 4-chlorooctane and 2-ethylhexyl thioglyconate, which is a by-product of organotin heat stabilizer. ${ }^{161}$ However, EGA-GC-MS detects VOCs emitted at high temperatures, and it may not be representative of normal conditions of use. 
Heritage objects are sometimes stored by wrapping. Silk, LDPE and polyethylene terephthalate (PET) were tested as wrapping materials for the storage of old and model PVC films. ${ }^{162,163}$ Bulk and surface properties were measured during accelerated degradation of PVC with different wrapping materials. Colour change was the most significant for PET, followed by LDPE. Silk paper affected neither discolouration nor the rate of degradation. Migration of DOP plasticizer from PVC sample to LDPE was observed as an increase of mass for LDPE and as the presence of characteristic absorption bands by FTIR spectroscopy on LDPE. PVC stored in PET showed a presence of phthalic acid from DOP degradation, not present in other cases of storage. ${ }^{163}$

Museum objects need regular care and maintenance to prevent the accumulation of soiling. Cleaning of PVC objects can be carried out using solvents or dry-cleaning methods. Water, detergent solutions, alkaline solutions, polar and non-polar organic solvents (ethanol, iso-propanol, heptane), aqueous-organic mixtures, detergents and alkaline solutions have all been used. ${ }^{59,164-166} \mathrm{~A}$ study evaluated cleaning of undamaged and of photodegraded plasticized PVC objects by ATR-FTIR spectroscopy. Pure organic solvents were found to be unsuitable for cleaning undamaged and photo-degraded PVC objects, because of plasticizer extraction. Cleaning with deionized water, and mixtures with small proportions of organic solvents, a $\mathrm{KOH}$ solution and a commercial detergent was found suitable. ${ }^{164}$ The study used FTIR spectroscopy, however, this may not be sensitive enough for the detection of small changes in the surface. Optical microscopy and non-contact profilometry were used to evaluate the cleaning efficiency and found aqueous solutions of $\mathrm{KOH}$ to be too aggressive for conservation and a commercial cleaning liquid was found more appropriate. ${ }^{165}$ FTIR, colorimetry, profilometry and optical microscopy have been used for evaluating the efficiency of soiling removal using dry cleaning. ${ }^{59,166}$ Cotton swabs were the least suitable for removal of dirt particles, because they changed surface topography by producing ridges, and caused the plasticizer to migrate to the surface. ${ }^{166} \mathrm{PEL}$ cloths from polyester/polyamide fibers created a slightly rougher surface but were considered the safest dry-cleaning materials, because dirt is removed due to static cling.

The degradation of plastic objects in museums does not result solely in the loss of integrity and value of the object itself but can lead to deterioration of objects in its vicinity due to the emission of harmful substances e.g. acidic gasses. Organisation of collections by plastic type may thus be a suitable strategy for successful preservation and storage of plastic objects.

Studies of the accelerated degradation of PVC below $100{ }^{\circ} \mathrm{C}$ are rare. So far, Shashoua's ${ }^{57}$ study was carried out at $70{ }^{\circ} \mathrm{C}$ and Royaux ${ }^{59,163}$ carried out two studies with a temperatures fluctuation at $65^{\circ} \mathrm{C}$ for two days and at $25^{\circ} \mathrm{C}$ for 1 day. Investigations of natural degradation of PVC ob- jects in different outdoor environments and comparison with accelerated degradation at higher temperatures can be problematic as processes of degradation can be different. Accelerated degradation is suitable with the assumption that the activation energy of the reaction remains the same when extrapolating to room temperature. ${ }^{167}$ Difficulties arise, whether even studies performed at $50{ }^{\circ} \mathrm{C}$ cannot correctly describe the ongoing processes of degradation. Table 1 shows that the glass-transition temperature of PVC objects with $20 \mathrm{wt}$. $\%$ of DEHP is $25^{\circ} \mathrm{C}$, so a transition occurs above this temperature. Because it is accompanied by changes in physical properties, a change in the activation energy of the degradation is expected. A relatively well-understood example relevant to heritage is degradation of paper, where one reaction dominates at temperatures $<100{ }^{\circ} \mathrm{C}$, while the other predominates $>100{ }^{\circ} \mathrm{C}$. Therefore, the investigations of paper stability should be carried out at temperatures below $100{ }^{\circ} \mathrm{C} .{ }^{25,168} \mathrm{~A}$ similar understanding of the potential for phase transitions affecting the degradation behaviour of PVC is needed.

\section{Conclusions}

Plastic materials in collections often exhibit advanced stages of degradation that are rarely observed in commodity products and applications, such as discolouration, warping, cracking and surface exudation, which is undesirable in the context of long-term conservation. These processes may be difficult to manage because conservation guidelines are often not polymer-specific. Advanced degradation is often visible and thus aesthetically displeasing for conservators and museum visitors. This literature overview revealed the following gaps in the understanding of PVC degradation as relevant to conservation and collection management:

- Degradation at temperatures below Tg

- The role of plasticizers in the process of PVC degradation, the role of plasticizer compatibility and the influence of its migration

- Surface accumulation of plasticizer

- $\mathrm{HCl}$ elimination and emission at temperatures of storage and display

- Combined influence of temperature, relative humidity, pollutants and air velocity on the degradation of PVC (damage function).

Most of the published studies of PVC degradation have focused on $\mathrm{HCl}$ elimination kinetics, thermogravimetric analysis or degradation due to outdoor weathering. Studies of accelerated degradation have mostly been carried out at temperatures above $100{ }^{\circ} \mathrm{C}$, which is higher than the glass transition temperature and melting temperature of crystalline PVC. Such research is relevant for reprocessing and combustion studies, but the resulting knowledge may not be directly applicable to museum conditions. Unfortunately, reasonable predictions are expect- 
ed only from studies carried out by accelerated degradation at moderately elevated temperatures.

It is well known that the degradation of PVC involves elimination of hydrogen chloride with the formation of polyene sequences that cause discolouration of the object. In addition, plasticizers are major components of flexible $\mathrm{PVC}$ and they are prone to migration within the material, followed by evaporation or by extraction into materials in direct contact. The role of plasticizers on the stability and degradation of PVC cannot be easily generalized as it significantly depends on the plasticizer type, presence of thermal stabilizers and other additives. The loss of plasticizer depends on the temperature, plasticizer volatility and the airflow rate above the surface. Studies of accelerated degradation demonstrated that the degradation of plasticized PVC objects was higher in open environments when compared to closed environments, where loss of plasticizer was limited. Research has shown that the presence of sorbents negatively affected the state of PVC objects. Sorbents meant to remove harmful acidic emissions are not selective and increase the rate of plasticizer evaporation. In addition, the discolouration had also increased. There seems to be a lack of clear evidence on how temperature affects solubility of plasticizer in PVC and the increased rate of plasticizer migration with evaporation observed at elevated temperatures. Such research would be of tremendous help in selecting optimal storage conditions.

Degradation of three-dimensional art objects is especially concerning because their importance and value is often directly linked to their structural integrity. Different mechanisms of degradation are relevant for three-dimensional PVC objects based on their geometry, presence of specific plasticizers, stabilizers and other additives, and the history of previous storage conditions. For objects made of thin PVC with large and exposed surfaces, the main degradation pathway is likely to be loss of plasticizer due to evaporation. Objects from thick PVC are more likely to exhibit degradation by elimination of $\mathrm{HCl}$, because the emitted gas remains in the matrix longer and acts autocatalytically.

Management of plastics collections requires guidelines for proper storage. The main degradation factors for many plastics are still unknown and may differ greatly. For example, storage of cellulose nitrate and cellulose acetate requires sorbents and high air circulation to avoid the autocatalytic degradation due to emission of $\mathrm{NO}_{2}$ and acetic acid. The same conditions are inappropriate for PVC storage due to increased loss of plasticizer, exacerbating PVC degradation. Therefore, identification of the main degradation factors and their contribution to the overall rate of degradation of PVC is crucial for successful mitigation of long-term degradation. Dose-response functions need to be constructed to identify the relative contributions of the main degradation factors and thus aid collection managers in the decision-making process leading to the selection of appropriate storage conditions.
While the initial PVC degradation processes are relatively well-understood, being of industrial interest, plastic objects in museums are often past their intended lifetime as consumer plastics, from a polymer scientist's point of view. Unfortunately, this resulted in a lack of systematic research of advanced stages of material deterioration at indoor conditions. Such research is urgently needed in order to enable conservators and collection managers to make informed decisions regarding storage, display and cleaning of museum PVC objects.

So far, there have been very few studies on the PVC degradation at low temperatures. The mechanism of degradation, which can be different at the conditions of accelerated degradation at higher temperatures, has to be considered. For example, the degradation of museum PVC objects could be described by a dose-response function based on experiments carried out close to indoor conditions. On the other hand, the degradation of PVC objects intended for outdoor use should be studied by experiments involving weathering, including larger fluctuations of temperature and humidity and exposure to UV light.

\section{Declaration of interest}

The authors declare that they have no competing interests.

\section{Acknowledgements}

The work was financially supported by European Union's Horizon 2020 Research and In- novation Programme APACHE project (Grant Agreement ID: 814496), IPERION HS project (Grant Agreement ID: 871034) and the Slovenian Research Agency (Research Programme No. P1-0153) and was partly carried out in the frame of "Mobility of teachers at the University of Ljubljana 2018-2021 «, co-financed by the Republic of Slovenia and EU European Social Fund. The authors are grateful to Véronique Sorano Stedman (Centre Pompidou, Paris, France) for her kind assistance.

\section{References}

1. S. Patrick: Practical Guide to Polyvinyl Chloride 1st ed., Smithers Rapra Technology, Shawbury, UK, 2005.

2. Plastics - the Facts 2019, PlasticsEurope, 14.10.2019.

3. Y. Shashoua: Conservation of Plastics: Materials science, degradation and preservation. 1st Ed., Butterworth-Heinemann, Oxford, UK, 2008, pp. 113-222.

4. POPART (Preservation Of Plastic ARTefacts in museum collections), Introduction, C. Williamson: From blood and sawdust to lycra: 200 years of plastics in art \& design, http:// popart-highlights.mnhn.fr/index.html (accessed September 16, 2020).

5. POPART (Preservation Of Plastic ARTefacts in museum collections), Collection Survey, What is the condition of the 
collection?, http://popart-highlights.mnhn.fr/index.html (accessed September 17, 2020).

6. B. Keneghan, Museum Manag. Curatorsh. 2001, 19, 321331. DOI:10.1016/S0260-4779(01)00054-1

7. S. L. Molina, Ge-Conservacion 2017, 1, 278-285. DOI:10.37558/gec.v11i0.532

8. B. Lavédrine, A. Fournier, G. Martin: Collection Survey. In: CTHS Comité des travaux historiques et Scientifiques, ed. Preservation of Plastic Artefacts in Museum Collections., 2012, pp. 107-151.

9. J. Leadbitter, J. A. Day, J. L. Ryan: PVC: Compounds, Processing and Applications, Smithers Rapra Technology, Shawbury, UK, 1994.

10. I. D. Hounsham, W. V. Titow: Fillers in PVC, In: PVC Technology, Springer, Dordrecht, Netherlands, 1984, pp. 215254. DOI:10.1007/978-94-009-5614-8_8

11. G. Wypych: Handbook of Plasticizers 3rd Edition, ChemTec Publishing, Toronto, Canada, 2004, pp. 33, 119-134, 442462, 661-671.

12. G. Wypych: PVC Degradation and Stabilization 3rd ed., ChemTec Publishing, Toronto, Canada, 2015.

DOI:10.1016/B978-1-895198-85-0.50011-X

13. C. Bueno-Ferrer, M. C. Garrigós, A. Jiménez, Polym. Degrad. Stab. 2010, 95, 2207-2212.

DOI:10.1016/j.polymdegradstab.2010.01.027

14. W. H. Starnes, Prog. Polym. Sci. 2002, 27, 2133-2170.

DOI:10.1016/S0079-6700(02)00063-1

15. W. H. Starnes, X. Ge, Macromolecules 2004, 37, 352-359. DOI: $10.1021 / \mathrm{ma} 0352835$

16. W. H. Starnes, B. Du, S. Kim, V. G. Zaikov, X. Ge, E. K. Culyba, Thermochim. Acta 2006, 442, 78-80.

DOI:10.1016/j.tca.2006.01.018

17. K. Curran, M. Strlič, Stud. Conserv. 2015, 60, 1-14. DOI:10.1179/2047058413Y.0000000125

18. R. King, J. Grau-Bové, K. Curran, Herit. Sci. 2020, 8, 123. DOI:10.1186/s40494-020-00466-0

19. J. Yu, L. Sun, C. Ma, Y. Qiao, H. Yao, Waste Manag. 2016, 48, 300-314. DOI:10.1016/j.wasman.2015.11.041

20. F. Cappitelli, C. Sorlini, Appl. Environ. Microbiol. 2008, 74, 564-569. DOI:10.1128/AEM.01768-07

21. S. Buys, V. Oakley: Conservation and Restoration of Ceramics (Conservation \& Museology) 1st ed., Routledge, Abingdon, UK, 2014. DOI:10.4324/9780080502892

22. M. Rule, A. E. Charola, R. J. Koestler, V. Daniels, P. Garside, P. Wyeth, R. Thomson, D. Barker, H. Romich, Y. Shashoua, R. Inkpen, E. May, K. Petersen, M. Jones, R. Eaton, D. Gregory, H. Matthiesen, in E. May, M. Jones (Eds.): Conservation Science: Heritage Materials, The Royal Society of Chemistry, Cambridge, UK, 2006.

23. E. F. Doehne, C. A. Price: Stone Conservation : An Overview of Current Research 2nd ed., Getty Conservation Institute; Los Angeles, California, 2010.

24. E. Menart, G. De Bruin, M. Strlič, Polym. Degrad. Stab. 2011, 96, 2029-2039.

DOI:10.1016/j.polymdegradstab.2011.09.002

25. M. Strlič, C. M. Grossi, C. Dillon, N. Bell, K. Fouseki, P.
Brimblecombe, E. Menart, K. Ntanos, W. Lindsay, D. Thickett, F. France, G. De Bruin, Herit. Sci. 2015, 1-11.

DOI:10.1186/s40494-015-0065-y

26. M. M. Brooks, D. D. Eastop (Eds.): Changing Views of Textile Conservation, Getty Conservation Institute, Los Angeles, California, 2011.

27. Y. Shashoua: Inhibiting the inevitable; current approaches to slowing the deterioration of plastics: Macromolecular Symposia, Vol 238. John Wiley \& Sons, Ltd; 2006, pp. 67-77. DOI:10.1002/masy.200650610

28. A. Burnstock, K. J. van den Berg: Twentieth Century Oil Paint. The Interface Between Science and Conservation and the Challenges for Modern Oil Paint Research, in: Issues in Contemporary Oil Paint. Springer International Publishing, New York, 2014, pp. 1-19. DOI:10.1007/978-3-319-10100-2_1

29. K. Curran, A. Možir, M. Underhill, L. T. Gibson, T. Fearn, M. Strlič, Polym. Degrad. Stab. 2014, 107, 294-306. DOI:10.1016/j.polymdegradstab.2013.12.019

30. S. N. Lakeev, I. O. Maydanova, R. F. Mullakhmetov, O. V. Davydova, 2016, 89, 1-15. DOI:10.1134/S1070427216010018

31. B. Pelzl, R. Wolf, B. L. Kaul: Plastics, Additives, in: Ullmann's Encyclopedia of Industrial Chemistry, Wiley-VCH, Weinheim, Germany, 2012, pp. 619-671.

32. Phthalates ActionPlan, U.S. Environmental Protection Agency, 14.3.2012.

33. A. Wypych: Databook of Plasticizers 2nd Edition, ChemTec Publishing, Toronto, Canada, 2012, pp. 480-483, 506-508, 523-525.

34. S. S. S. Rowdhwal, J. Chen, Biomed Res. Int. 2018, 2018. DOI: $10.1155 / 2018 / 1750368$

35. USA's Consumer Product Safety Improvement Act of 2008 - Public Law 110-314-Aug. 14.8.2008.

36. E. Eckert, F. Münch, T. Göen, A. Purbojo, J. Müller, R. Cesnjevar, Chemosphere 2016, 145, 10-16. DOI:10.1016/j.chemosphere.2015.11.067

37. A. Greco, F. Ferrari, A. Maffezzoli, J. Clean. Prod. 2017, 164, 757-764. DOI:10.1016/j.jclepro.2017.07.009

38. S. Mukherjee, M. Ghosh, JAOCS, J. Am. Oil Chem. Soc. 2020, 97, 187-199. DOI:10.1002/aocs.12294

39. A. Carbonell-verdu, D. Garcia-sanoguera, A. Jord, L. Sanchez-nacher, R. Balart, 2016, 43642, 1-10. DOI:10.1016/j.eurpolymj.2014.11.043

40. J. Chen, Z. Liu, J. Jiang, X. Nie, Y. Zhou, R. E. Murray, RSC Adv. 2015, 5, 56171-56180. DOI:10.1039/C5RA07096A

41. S. Kumar, Ind. Eng. Chem. Res. 2019, 58, 11659-11672. DOI:10.1021/acs.iecr.9b02080

42. P. Karmalm, T. Hjertberg, A. Jansson, R. Dahl, Polym. Degrad. Stab. 2009, 94, 2275-2281.

DOI:10.1016/j.polymdegradstab.2009.07.019

43. P. H. Daniels, J Vinyl Addit. Technol 2009, 21, 129-133. DOI:10.1002/vnl.20211

44. W. Aiken, T. Alfrey, A. Janssen, H. Mark, J. Polym. Sci. 1947, 2, 178-198. DOI:10.1002/pol.1947.120020206

45. P. Walters, D. F. Cadogan, C. J. Howick: Plasticizers in: Ull- 
mann's Encyclopedia of Industrial Chemistry, Wiley-VCH, Weinheim, Germany, 2020, pp. 1-27.

DOI:10.1002/14356007.a20_439.pub2

46. K. A. Mauritz, R. F. Storey, B. S. Wilson, J. Vinyl Addit. Technol. 1990, 12, 165-173. DOI:10.1002/vnl.730120309

47. T. Vilics, H. A. Schneider, V. Manoviciu, I. Manoviciu, Polymer (Guildf). 1997, 38, 1865-1870.

DOI:10.1016/S0032-3861(96)00722-7

48. N. Kinjo, T. Nakagawa, Polym. J. 1973, 4, 143-153.

DOI:10.1295/polymj.4.143

49. ASM International: Characterization and Failure Analysis of Plastics. (Lampman S, ed.). ASM International; 2003.

50. M. Hakkarainen: Migration of monomeric and polymeric PVC plasticizers, in: Advances in Polymer Science Vol 211., 2008,pp.159-185. DOI:10.1007/12_2008_140

51. M. Ekelund, B. Azhdar, U. W. Gedde, Polym. Degrad. Stab. 2010, 95, 1789-1793.

DOI:10.1016/j.polymdegradstab.2010.05.007

52. L. Monney, M. Jamois-Tasserie, C. Dubois, P. Lallet, F. Villa, C. Renaud, Polym. Degrad. Stab. 2001, 72, 459-468. DOI:10.1016/S0141-3910(01)00047-7

53. P. Hadi, A. A. Babaluo, J. Appl. Polym. Sci. 2007, 106, 39673974. DOI:10.1002/app.27045

54. J. P. Giroud, Geosynth. Int. 1995, 2, 1099-1113. DOI:10.1680/gein.2.0047

55. L. Audouin, B. Dalle, G. Metzger, J. Verdu, J. Appl. Polym. Sci. 1992, 45, 2091-2096. DOI:10.1002/app.1992.070451204

56. C. Wang, D. Johnson, M. A. Suleman, M. A. Suleman, W. Zhang, D. Pestov, P. Ramsinghani, R. Wickham, K. J. Wynne, Polymer (Guildf). 2015, 76, 70-79. DOI:10.1016/j.polymer.2015.08.048

57. Y. R. Shashoua, Polym. Degrad. Stab. 2003, 81, 29-36. DOI:10.1016/S0141-3910(03)00059-4

58. X.-F. Wei, E. Linde, M. S. Hedenqvist, npj Mater. Degrad. 2019, 3, 1-8. DOI:10.1038/s41529-019-0080-7

59. A. Royaux, I. Fabre-Francke, N. Balcar, G. Barabant, C. Bollard, B. Lavédrine, S. Cantin, Polym. Degrad. Stab. 2017, 137, 109-121. DOI:10.1016/j.polymdegradstab.2017.01.011

60. E. Linde, U.W. Gedde, Polym. Degrad. Stab. 2014, 101, 2431. DOI:10.1016/j.polymdegradstab.2014.01.021

61. P. A. Clausen, Y. Xu, V. Kofoed-Sørensen, J. C. Little, P. Wolkoff, Atmos. Environ. 2007, 41, 3217-3224. DOI:10.1016/j.atmosenv.2006.06.063

62. Ž. Mrklić, T. Kovačić, Thermochim. Acta 1998, 322, 129135. DOI:10.1016/S0040-6031(98)00479-1

63. H. M. Zhu, X. G. Jiang, J. H. Yan, Y. Chi, K. F. Cen, J. Anal. Appl. Pyrolysis 2008, 82, 1-9.

DOI:10.1016/j.jaap.2007.11.011

64. S. S. Suresh, S. Mohanty, S. K. Nayak, Waste Manag. 2017, 60, 100-111 DOI:10.1016/j.wasman.2016.08.033

65. D. Braun, Pure Appl. Chem. 1971, 26, 173-192.

DOI:10.1351/pac197126020173

66. D. Braun, B. Böhringer, W. Knoll, N. Eidam, W. Mao, Angew. Makromol. Chemie 1990, 181, 23-40.

DOI:10.1002/apmc.1990.051810102

67. Y. Shashoua: Inhibiting the deterioration of plasticized poly (vinyl chloride). Chem. Eng. 2001, PhD thesis.

68. R. Navarro, M. Pérez Perrino, M. Gomez Tardajos, H. Reinecke, Macromolecules. 2010, 43, 2377-2381.

DOI:10.1021/ma902740t

69. R. Navarro, M. Pérez Perrino, C. García, C. Elvira, A. Gallardo, H. Reinecke, Macromolecules 2016, 49, 2224-2227.

DOI:10.1021/acs.macromol.6b00214

70. P. M. R. Tendero, A. Jimenez, A. Greco, A. Maffezzoli, Eur. Polym. J. 2006, 42, 961-969.

DOI:10.1016/j.eurpolymj.2005.10.006

71. Y. Ma, S. Liao, Q. Li, Q. Guan, P. Jia, Y. Zhou, React. Funct. Polym. 2020, 147, 104458.

DOI:10.1016/j.reactfunctpolym.2019.104458

72. K. Patel, A. Velazquez, H.S. Calderon, G.R. Brown, J. Appl. Polym. Sci. 1992, 46, 179-187.

DOI:10.1002/app.1992.070460117

73. M. Carenza, Y. V. Moiseev, G. Palma, J. Appl. Polym. Sci. 1973, 17, 2685-2694. DOI:10.1002/app.1973.070170905

74. B. B. Troitskii, L. S. Troitskaya, V. N. Denisova, Z.B. Luzinova, Polym. J. 1978, 10,377-385. DOI:10.1295/polymj.10.377

75. A. A. Yassin, M. W. Sabaa, J. Macromol. Sci. Part C 1990, 30, 491-558. DOI:10.1080/07366579008050916

76. W. H. Starnes Jr., S. Girois, in: R. A. Pethrick (Ed.).: Polymer Yearbook 1995 12th ed., Gordon \& Breach, Boston, Massachusetts, 1995.

77. J. Purmová, K. F. D. Pauwels, M. Agostini, M. Bruinsma, E. J. Vorenkamp, A. J. Schouten, M. L. Coote, Macromolecules 2008, 41, 5527-5539. DOI:10.1021/ma800583k

78. W. H. Starnes, B. J. Wojciechowski, H. Chung, G. M. Benedikt, G. S. Park, A. H. Saremi, Macromolecules 1995, 28, 945-949. DOI:10.1021/ma00108a023

79. W. H. Starnes, B. J. Wojciechowski, A. Velazques, G. M. Benedikt, Macromolecules. 1992, 25, 3638-3641.

DOI:10.1021/ma00040a006

80. N. Boughdady, K. Chynoweth, D. Hewitt, Aust. J. Chem. 1991, 44, 567. DOI:10.1071/CH9910567

81. Z. Mayer, J. Macromol. Sci. Part C 1974, 10, 263-292. DOI:10.1080/15321797408076100

82. Z. Mayer, B. Obereigner, D. Lim, J. Polym. Sci. Part C Polym. Symp. 2007, 33, 289-305. DOI:10.1002/polc.5070330128

83. R. Bacaloglu, M. H. Fisch, Polym Degrad Stab 1994, 45, 301313. DOI:10.1016/0141-3910(94)90200-3

84. M. H. Fisch, R. Bacaloglu, J. Vinyl Addit. Technol. 1995, 1, 233-240. DOI:10.1002/vnl.730010409

85. K. Endo, In: Progress in Polymer Science, Pergamon, Oxford, UK, 2002, pp. 2021-2054.

DOI:10.1016/S0079-6700(02)00066-7

86. W. H. Starnes Jr., Polym. Mater. Sci. Eng. 1988, 58, 220.

87. T. Y. Xie, A.E. Hamielec, M. Rogestedt, T. Hjertberg, Polymer (Guildf). 1994, 35, 1526-1534.

DOI:10.1016/0032-3861(94)90354-9

88. W. H. Starnes, I. M. Plitz, D. C. Hische, D. J. Freed, F. C. Schilling, M.L. Schilling, Macromolecules 1978, 11, 373-382. DOI:10.1021/ma60062a019

89. G. Szarka, B. Iván, J. Macromol. Sci. Part A Pure Appl. Chem. 2013, 50, 208-214. DOI:10.1080/10601325.2013.742804 
90. J. P. H. M. Hillemans, C. M. C. J. Colemonts, R. J. Meier, B. J. Kip, Polym. Degrad. Stab. 1993, 42, 323-333. DOI:10.1016/0141-3910(93)90228-B

91. K. S. Minsker, S. V. Kolesov, G. E. Zaikov: Degradation and stabilization of vinyl chloride-based polymers 1st Edition, Pergamon, Oxford, UK, 1988.

92. B. B. Troitskii, L. S. Troitskaya, A. S. Yakhnov, M. A. Novikova, V. N. Denisova, V. K. Cherkasov, M.P. Bubnov, Polym. Degrad. Stab. 1997, 58, 83-89.

DOI:10.1016/S0141-3910(97)00023-2

93. G. Martinez, C. Mijangos, J. Millan, J. Appl. Polym. Sci. 1983, 28, 33-43. DOI:10.1002/app.1983.070280104

94. B. B. Troitskii, A. S. Yakhnov, M. A. Novikova, T. G. Ganyukhina, V. N. Denisova, Eur. Polym. J. 1997, 33, 505-511. DOI:10.1016/S0014-3057(96)00190-5

95. R. Flores, J. Perez, P. Cassagnau, A. Michel, J. Y. Cavaillé, Polymer (Guildf). 1994, 35, 2800-2807. DOI:10.1016/0032-3861(94)90309-3

96. R. P. Chartoff, T. S. K. Lo, E. R. J. Harrell, R. Joon Roe, J. Macromol. Sci. Part B 1981, 20, 287-303. DOI:10.1080/00222348108219443

97. G. A. Voyiatzis, K. S. Andrikopoulos, G. N. Papatheodorou, E. I. Kamitsos, G. D. Chryssikos, J. A. Kapoutsis, S. H. Anastasiadis, G. Fytas, Macromolecules 2000, 33, 5613-5623. DOI:10.1021/ma991772m

98. S. Ulutan, J. Appl. Polym. Sci. 2003, 90, 3994-3999. DOI:10.1002/app.13133

99. R. Chen, D. R. Tyler, Macromolecules 2004, 37, 5430-5436. DOI: $10.1021 / \mathrm{ma} 0496302$

100. C. Tsitsilianis, M. Tsapatsis, C. Economou, Polymer (Guildf). 1989, 30, 1861-1866. DOI:10.1016/0032-3861(89)90359-5

101. A. Marcilla, M. Beltrán, Polym. Degrad. Stab. 1998, 60, 1-10. DOI:10.1016/S0141-3910(96)00124-3

102. R. Zorn, M. Monkenbusch, D. Richter, A. Alegría, J. Colmenero, B. Farago, J. Chem. Phys. 2006, 125, 154904. DOI: $10.1063 / 1.2357738$

103. V. K.-H. Illers, Die Makromol. Chemie 1969, 127, 1-33. DOI:10.1002/macp.1969.021270101

104. S. T. Bee, W. R. Mok, T. S. Lee, T. T. Tee, G. Issabayeva, A. R. Rahmat, J. Polym. Eng. 2014, 34, 521-529.

DOI:10.1515/polyeng-2013-0324

105. M. Beltrán, J. C. García, A. Marcilla, Eur. Polym. J. 1997, 33, 453-462. DOI:10.1016/S0014-3057(96)00213-3

106. E. B. Rabinovitch, J. W. Summers, J. Vinyl Technol. 1992, 14, 126-130. DOI:10.1002/vnl.730140303

107. B. J. Kip, R. J. Meier, M. van Aaken, K. P. J. Williams, D. L. Gerrard, Macromolecules 1992, 25, 4290-4296.

DOI:10.1021/ma00043a008

108. H. Shirakawa, T. Ito, S. Ikeda, Die Makromol. Chemie 1978, 179, 1565-1573. DOI:10.1002/macp.1978.021790615

109. T. Yamabe, K. Akagi, K. Ohzeki, K. Fukui, H. Shirakawa, J. Phys. Chem. Solids 1982, 43, 577-581.

DOI:10.1016/0022-3697(82)90047-6

110. J. Lemaire, N. Siampiringue, N. Girod, P. Delprat, G. Parmeland, N. Macdonald, C. Spriet, J. Vinyl Addit. Technol. 2003, 9, 54-60. DOI:10.1002/vnl.10063
111. E. Arkiş, D. Balköse, Polym. Degrad. Stab. 2005, 88, 46-51. DOI:10.1016/j.polymdegradstab.2004.02.021

112. J. Oremusová, P. Šimon, L. Valko, P. Kovařík, Chem. Pap. 1989, 43, 721-731.

113. J. F. Rabek, J. Lucki, H. Kereszti, T. Hjertberg, Q.B. Jun, J. Appl. Polym. Sci. 1990, 39, 1569-1586.

DOI:10.1002/app.1990.070390714

114. A. Michel, J. Macromol. Sci. Part A - Chem. 1978, 12, 361371. DOI:10.1080/00222337808061385

115. A. H. Frye, R. W. Horst, J. Polym. Sci. 1959, 40, 419-431. DOI:10.1002/pol.1959.1204013712

116. V. H. Tran, A. Guyot, T. P. Nguyen, P. Molinié, Polym. Degrad. Stab. 1995, 49, 331-337.

DOI:10.1016/0141-3910(95)00075-W

117. Omnexus, The material selection platform, Polymer Properties, Water Absorption 24 hours, https://omnexus.specialchem.com/polymer-properties/properties/water-absorption-24-hours, 14.9.2020.

118. Y. Hu, J. Summers, A. Hiltner, E. Baer, J. Vinyl Addit. Technol. 2002, 8, 251-258. DOI:10.1002/vnl.10371

119. L. Laiarinandrasana, E. Gaudichet, S. Oberti, C. Devilliers, Int. J. Press. Vessel. Pip. 2011, 88, 99-108.

DOI:10.1016/j.ijpvp.2011.01.002

120. N. Belhaneche-Bensemra, J. Vinyl Addit. Technol. 2002, 8, 45-54. DOI:10.1002/vnl.10344

121. M. Ito, K. Nagai, Polym. Degrad. Stab. 2007, 92, 260-270. DOI:10.1016/j.polymdegradstab.2006.11.003

122. M. Lenartowicz, B. Swinarew, A. Swinarew, G. Rymarz, Int. J. Polym. Anal. Charact. 2014, 19, 611-624. DOI:10.1080/1023666X.2014.933071

123. J. Colombani, V. Labed, C. Joussot-Dubien, A. Périchaud, J. Raffi, J. Kister, C. Rossi, Nucl. Instruments Methods Phys. Res. Sect. B Beam Interact. with Mater. Atoms 2007, 265, 238-244. DOI:10.1016/j.nimb.2007.08.053

124. Z. Dobkowski, Polym. Degrad. Stab. 2006, 91, 488-493. DOI:10.1016/j.polymdegradstab.2005.01.051

125. J. Verdu, J. Macromol. Sci. Part A - Chem. 1978, 12, 551-567.

126. L. E. Pimentel Real, A. M. Ferraria, A. M. Botelho do Rego, Polym. Test. 2008, 27, 743-751.

DOI:10.1016/j.polymertesting.2008.05.009

127. W. H. Starnes, In: S. Peter Pappas, F. H. Winslow (Eds.): Photodegradation of Polyvinyl Chloride, ACS Publications, Washington D, Washington, 1981, pp. 197-215. DOI:10.1021/bk-1981-0151.ch014

128. U. Gesenhues, Polym. Degrad. Stab. 2000, 68, 185-196. DOI:10.1016/S0141-3910(99)00184-6

129. A. Torikai, H. Hasegawa, Polym. Degrad. Stab. 1999, 63, 441-445. DOI:10.1016/S0141-3910(98)00125-6

130. A. L. Andrady, K. Fueki, A. Torikai, J. Appl. Polym. Sci. 1990, 39, 763-766. DOI:10.1002/app.1990.070390325

131. J. L. Gardette, J. Lemaire, J. Vinyl Addit. Technol. 1997, 3, 107-111. DOI:10.1002/vnl.10175

132. A. L. Andrady, A. Torikai, K. Fueki, J. Appl. Polym. Sci. 1989, 37, 935-946.

133. J. Ashley-Smith, A. Derbyshire, B. Pretzel, I.C. for Conservation: The continuing development of a practical lighting 
policy for works of art on paper and other object types at the Victoria and Albert Museum. 13th Triennial Meeting, Rio de Janiero, 22-27 September 2002, London, UK, 2002, pp. 3-8.

134. G. Pastorelli, C. Cucci, O. Garcia, G. Piantanida, A. Elnaggar, M. Cassar, M. Strlič, Polym. Degrad. Stab. 2014, 107, 198-209. DOI:10.1016/j.polymdegradstab.2013.11.007

135. M. Edge, C. M. Liauw, N. S. Allen, R. Herrero, Polym. Degrad. Stab. 2010, 95, 2022-2040.

DOI:10.1016/j.polymdegradstab.2010.07.006

136. V. D. Daniels, N. H. Rees, J Polym Sci 1974, 12, 2115-2122. DOI:10.1002/pol.1974.170120929

137. R. B. Woodward, J. Am. Chem. Soc. 1941, 63, 1123-1126. DOI:10.1021/ja01849a066

138. G. N. Lewis, M. Calvin, Chem. Rev. 1939, 25, 273-328. DOI:10.1021/cr60081a004

139. G. Ocskay, Z. Nyitraj, F. Varflavi, T. Wein, Eur. Polym. J. 1971, 7, 1135-1145. DOI:10.1016/0014-3057(71)90146-7

140. S. Hollande, J. L. Laurent, Polym. Degrad. Stab. 1997, 55, 141-145. DOI:10.1016/S0141-3910(96)00165-6

141. M. Wijdekop, J.C. Arnold, M. Evans, V. John, A. Lloyd, Mater. Sci. Technol. 2013, 21, 791-797.

DOI:10.1179/174328405X47500

142. ISO 182 Plastics - Determination of the tendency of compounds and products based on vinyl chloride homopolymers and copolymers to evolve hydrogen chloride and any other acidic products at elevated temperatures.

143. B. Lundgren, Indoor Air 1999, 9, 202-208. DOI:10.1111/j.1600-0668.1999.t01-1-00007.x

144. D. J. Carlsson, M. Krzymien, D. J. Worsfold, M. Day, J. Vinyl Addit. Technol. 1997, 3, 100-106. DOI:10.1002/vnl.10174

145. G. Mitchell, C. Higgitt, L. T. Gibson, Polym. Degrad. Stab. 2014, 107, 328-340.

DOI:10.1016/j.polymdegradstab.2013.12.003

146. S. Panseri, L. M. Chiesa, A. Zecconi, G. Soncini, I. De Noni, Molecules 2014, 19, 8707-8724.

DOI:10.3390/molecules19078707

147. M. Noguchi, A. Yamasaki, Heliyon 2020, 6, e03314. DOI:10.1016/j.heliyon.2020.e03314

148. K. Curran, M. Underhill, J. Grau-Bové, T. Fearn, L. T. Gibson, M. Strlič, Angew. Chemie - Int. Ed. 2018, 57, 7336-7340. DOI:10.1002/anie.201712278

149. G. Mitchell, F. France, A. Nordon, P. L. Tang, L. T. Gibson, Herit. Sci. 2013, 1, 1-10. DOI:10.1186/2050-7445-1-28

150. G. Pastorelli, T. Trafela, P.F. Taday, A. Portieri, D. Lowe, K. Fukunaga, M. Strlič, Anal. Bioanal. Chem. 2012, 403, 14051414. DOI:10.1007/s00216-012-5931-9

151. Y. Shashoua, Stud. Conserv. 2004, 49, 91-95. DOI:10.1179/sic.2004.49.s2.020

152. C. B. Lauridsen, L. W. Hansen, T. Brock-Nannestad, J. Bendix, K. P. Simonsen, Stud. Conserv. 2017, 62, 445-455.

DOI:10.1080/00393630.2016.1206651

153. D. Saviello, L. Andena, D. Gastaldi, L. Toniolo, S. Goidanich, J. Appl. Polym. Sci. 2018, 135, 1-12.

DOI:10.1002/app.46194

154. K. Z. Gumargalieva, V. B. Ivanov, G. E. Zaikov, J. V. Moiseev,
T. V. Pokholok, Polym. Degrad. Stab. 1996, 52, 73-79.

DOI:10.1016/0141-3910(95)00209-X

155. J. Puls, S. A. Wilson, D. Hölter, J. Polym. Environ. 2011, 19, 152-165. DOI:10.1007/s10924-010-0258-0

156. Y. Shashoua, S. M. Bradley, V. D. Daniels, Stud. Conserv. 1992, 37, 113. DOI:10.2307/1506403

157. L. Robinet, D. Thickett, Stud. Conserv. 2004, 48, 263-268. DOI:10.1179/sic.2003.48.4.263

158. G. G. Beiner, M. Lavi, H. Seri, A. Rossin, O. Lev, J. Gun, R. Rabinovich, Collect. Forum 2015, 29, 22-36.

DOI:10.14351/0831-4985-29.1.22

159. M. J. Samide, G. D. Smith, J. Chromatogr. A 2015, 1426, 201208. DOI:10.1016/j.chroma.2015.11.066

160. E. Canosa, A. Wiman, S. Norrehed, M. Hacke, Characterization of Emissions from Display Case Materials - Tecnical Report June 2019, Swedish National Heritage Board, 2019.

161. M. J. Samide, M. C. Liggett, J. Mill, G. D. Smith, Herit. Sci. 2018, 6, 1-10. DOI:10.1186/s40494-018-0213-2

162. A. Royaux, I. Fabre-Francke, N. Balcar, G. Barabant, C. Bollard, B. Lavédrine, S. Cantin, Polym. Degrad. Stab. 2018, 155, 183-193. DOI:10.1016/j.polymdegradstab.2018.07.016

163. A. Royaux, E. Apchain, I. Fabre-Francke, N. Balcar, G. Barabant, C. Bollard, B. Lavédrine, O. Fichet, S. Cantin, J. Cult. Herit. August 2020. DOI:10.1016/j.culher.2020.07.002

164. C. M. Muñoz, H. Egsgaard, J. S. Landaluze, C. Dietz, J. Am. Inst. Conserv. 2014, 53, 236-251.

DOI:10.1179/0197136014Z.00000000040

165. C. M. Muñoz, J. Microsc. 2011, 243, 257-266. DOI:10.1111/j.1365-2818.2011.03499.x

166. C. Morales Muñoz, Appl. Surf. Sci. 2010, 256, 3567-3572. DOI:10.1016/j.apsusc.2009.12.156

167. M. Strlič, D. Thickett, J. Taylor, M. Cassar, Stud. Conserv. 2013, 58, 80-87. DOI:10.1179/2047058412Y.0000000073

168. X. Zou, T. Uesaka, N. Gurnagul, Cellulose 1996, 3, 243-267. DOI:10.1007/BF02228805 


\section{Povzetek}

$\mathrm{V}$ muzejih in galerijah so vse večje zbirke predmetov in sodobne umetnosti, ki so iz plastičnih materialov, ki se lahko hitro spreminjajo. Glavni procesi razgradnje polivinil klorida (PVC) so eliminacija HCl ter migracija ali izguba mehčal. Posledica teh procesov je opazna obarvanost, togost in krhkost. Znano je, da je razgradnja večstopenjski proces, ki vključuje eliminacijo $\mathrm{HCl}$, nastanek konjugiranih polienov in zamreženje. Eliminacija $\mathrm{HCl}$ se začne zaradi strukturnih nepravilnosti (alilni in terciarni kloridi) in povzroči nastanek polienov. Spremembo barve PVC vidimo, ko nastane vsaj 7 konjugiranih dvojnih vezi.

Za identifikacijo polimerov in kvantifikacijo mehčal se uporabljajo neinvazivne tehnike, kot sta IR in Ramanska spektroskopija. Razgradnjo mehčal in zlasti pozne faze razgradnje PVC je mogoče raziskati s SEC, GC-MS, TGA in DSC. Študije v zbirkah dediščine so pokazale, da se poleg $\mathrm{HCl}$ iz PVC predmetov emitirajo tudi 2-etilheksanol in drugi hlapni razgradni produkti, vendar trenutno ni navedb, da se $\mathrm{HCl}$ emitira pri običajnih notranjih pogojih. Na splošno ni sistematičnih raziskav razgradnje PVC v pogojih skladiščenja in razstavljanja, kar bi omogočilo razvoj funkcije doza-odziv in oblikovanje smernic preventivnega konserviranja za upravljanje zbirk PVC. 